\title{
Coumarin-Derived Fluorescent Chemosensors
}

\author{
Hongqi Li, Li Cai and Zhen Chen \\ College of Chemistry, \\ Chemical Engineering and Biotechnology, \\ Donghua University, Shanghai,
}

China

\section{Introduction}

Fluorescent chemosensors are highly valuable in a variety of fields including environmental chemistry, analytical chemistry, and bio-medicinal science. They have provided accurate, on-line, and low-cost detection of toxic heavy metal ions, anions, and enzymes with high selectivity and sensitivity. Coumarins, with the structure of benzopyrone, have many advantages including high fluorescence quantum yield, large Stokes shift, excellent light stability, and less toxicity. Therefore coumarins have been widely used in the fields of biology, medicine, perfumes, cosmetics, and fluorescent dyes. By far coumarin derivatives have been used as fluorescent probes of $\mathrm{pH}$, for detection of nitric oxide, nitroxide, and hydrogen peroxide. Moreover, coumarin derivatives have served as good chemosensors of anions including cyanide, fluoride, pyrophosphate, acetate, benzoate, and dihydrogenphosphate as well as various metal ions comprised of $\mathrm{Hg}(\mathrm{II}), \mathrm{Cu}(\mathrm{II}), \mathrm{Zn}(\mathrm{II}), \mathrm{Ni}(\mathrm{II}), \mathrm{Ca}(\mathrm{II}), \mathrm{Pb}(\mathrm{II}), \mathrm{Mg}(\mathrm{II}), \mathrm{Fe}(\mathrm{III}), \mathrm{Al}(\mathrm{III}), \mathrm{Cr}(\mathrm{III})$, and Ag(I). Several systems containing coumarin exhibited simultaneous sensitivity toward two or more different metal ions, e.g. $\mathrm{Ca}(\mathrm{II})$ and $\mathrm{Mg}(\mathrm{II}), \mathrm{Ni}(\mathrm{II})$ and $\mathrm{Co}(\mathrm{II}), \mathrm{Cu}(\mathrm{II})$ and $\mathrm{Hg}(\mathrm{II}), \mathrm{Na}(\mathrm{I})$ and $\mathrm{K}(\mathrm{I}), \mathrm{Cu}(\mathrm{II})$ and $\mathrm{Ni}(\mathrm{II}), \mathrm{Hg}(\mathrm{II})$ and $\mathrm{Ag}(\mathrm{I}), \mathrm{Cu}(\mathrm{II}) / \mathrm{Ni}(\mathrm{II}) / \mathrm{Cd}(\mathrm{II}), \mathrm{Zn}(\mathrm{II}) / \mathrm{Cd}(\mathrm{II}) / \mathrm{Pb}(\mathrm{II})$, or $\mathrm{Ni}(\mathrm{II}) / \mathrm{Pd}(\mathrm{II}) / \mathrm{Ag}(\mathrm{I})$. Herein a brief review of fluorescent chemical sensors derived from coumarins is presented.

\section{Structural characteristics of coumarin}

The fusion of a pyrone ring with a benzene ring gives rise to a class of heterocyclic compounds known as benzopyrones, of which two distinct types are recognized, namely benzo- $\alpha$-pyrones, commonly called coumarins, and benzo- $\gamma$-pyrones, called chromones, the latter differing from the former only in the position of the carbonyl group in the heterocyclic ring as shown in Fig. 1 (Sethna \& Shah, 1945). It is well known that stilbene with a trans conformation is highly fluorescent. From the viewpoint of molecular structure, coumarins bear a carbon-carbon double bond which is fixed as trans conformation as in trans-stilbene through a lactone structure. This can help to avoid the trans-cis transformation of the double bond under ultraviolet (UV) irradiation as observed in stilbene compounds and results in strong fluorescence and high fluorescence quantum yield and photostability in most of coumarin derivatives. 


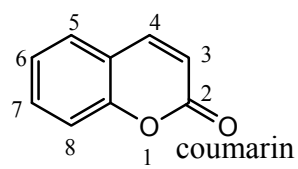<smiles>O=c1ccoc2ccccc12</smiles><smiles>CCNc1ccc2cc(/C=N/Nc3ccccc3)c(=O)oc2c1</smiles>

Fig. 1. Structures and numbering scheme of coumarin and related compounds

It was showed in the late 1950s that substitutions on the coumarin structure shifted the fluorescence band. For instance, adding a methyl group to the 4-position of 7-hydroxy- or 7methoxycoumarin red shifts the fluorescence spectra. Addition of electron-repelling groups in the 4-, 6-, or 7-position or electron-attracting groups in the 3-position all shifts the fluorescence band to longer wavelengths. When the carbonyl is substituted with a thione, the absorbance was red shifted and the fluorescence was quenched (Trenor et al., 2004). The reduction of the acceptor strength of the substituent at the 3-position, as in a 7diethylaminocoumarin dye $\mathbf{1}$ (the structure of which is shown in Fig. 1) does not always result in sustained fluorescence in polar, aprotic solvents. Thus 7-diethylamino-3styrylcoumarin dyes are not technically important as laser dyes; however, the extreme sensitivity of coumarin $\mathbf{1}$ to the medium polarity could provide an opportunity to probe the microenvironment experienced by the molecule (Bangar Raju \& Varadarajan, 1995).

Changing the solvent or the solution $\mathrm{pH}$ also affected the fluorescence spectra. Study on the effect of solution $\mathrm{pH}$ on 7-hydroxy-4-methylcoumarin showed that increasing the solution $\mathrm{pH}$ raised the fluorescence intensity. Studies on the effect of changing the solvent polarity on 13 coumarin derivatives revealed that increasing solvent polarity red shifted the absorbance as well as red shifted and broadened the emission of the coumarins due to increased hydrogen bonding. Studies on the excited-state properties of 4- and 7-substituted coumarin derivatives revealed that solvent polarity shifted both the emission and absorption peaks, with a greater shift observed in the emission spectra, indicating that the excited- state dipole moment of the solute molecule was greater than the ground-state dipole moment (Trenor et al., 2004).

\section{Coumarin-derived fluorescent chemosensors}

\subsection{Coumarin-derived fluorescent chemosensors for metal ions}

Considering the threat of mercury to the environment and human health, a great effort has been devoted to the utilization of fluorescent methods for detection of $\mathrm{Hg}^{2+}$ ions. More than ten coumarin-derived fluorescent chemosensors for $\mathrm{Hg}^{2+}$ ions have been reported. The structures and references of these chemical sensors are listed in Table 1.

The recognition mechanisms of these chemosensors mainly involve photoinduced electron transfer (PET), intramolecular charge transfer (ICT), fluorescence resonance energy transfer (FRET), coordination, and desulfurization. For instance, the fluorescence detection of 2 upon $\mathrm{Hg}^{2+}$ addition is promoted by a $\mathrm{Hg}^{2+}$-induced desulfurization of the thiourea moiety, leading to a decrease in an ICT character of the excited-state coumarin moiety (Shiraishi et al., 2010). Coumarin-thiazolobenzo-crown ether based chemosensor 3 has been developed for $\mathrm{Hg}$ (II) ions that utilizes the strong coordination of $\mathrm{Hg}(\mathrm{II})$ ions on the crown oxygen and thiazole nitrogen. The complexation of $\mathrm{Hg}$ (II) disrupts the ICT from the oxygen donor to the 


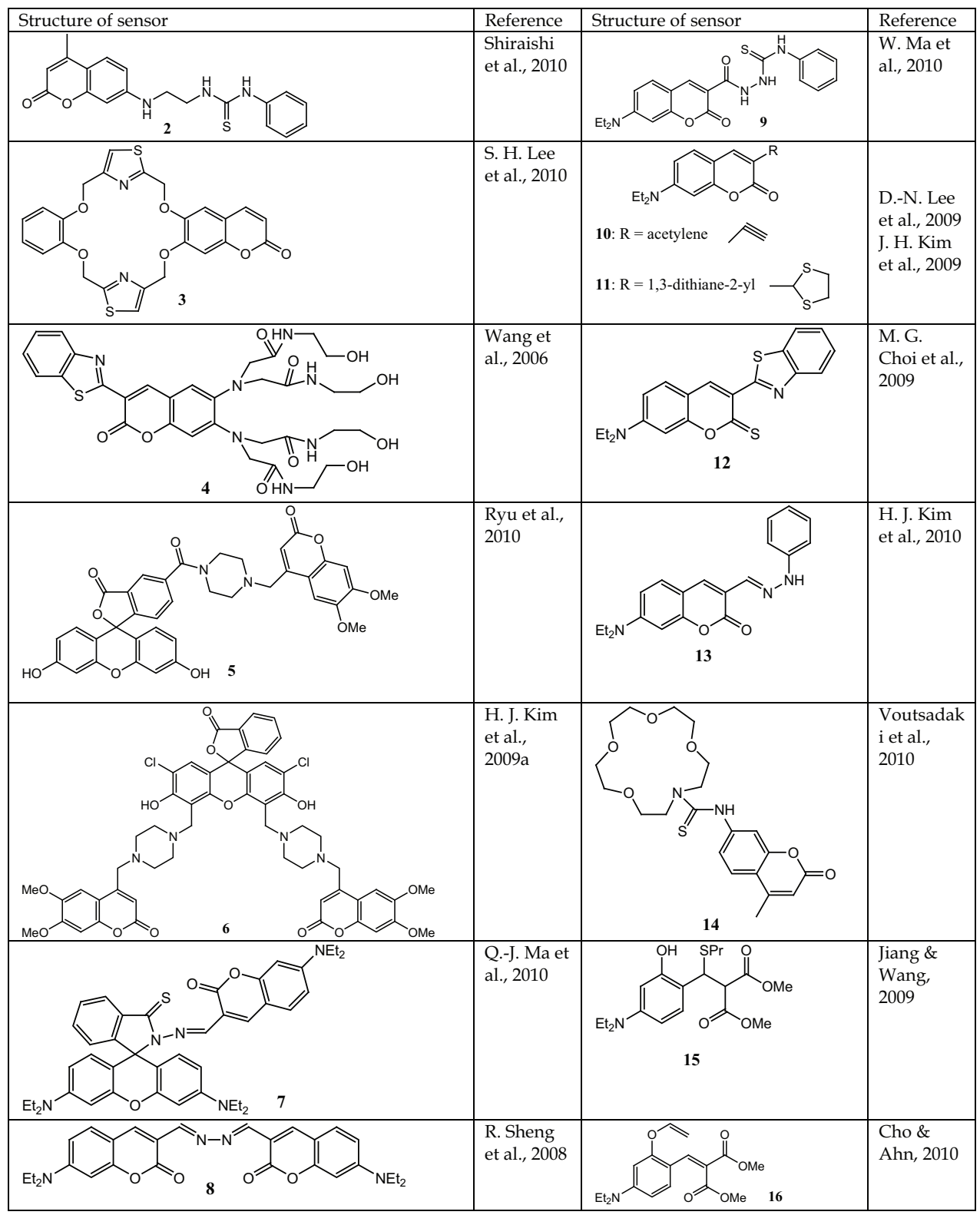

Table 1. Structures and references of coumarin-derived chemosensors for $\mathrm{Hg}$ (II) ions

coumarin fluorophore resulting in blue-shift in absorption and quenching of the fluorescence (S. H. Lee et al., 2010). The fluorescent ratiometric $\mathrm{Hg}^{2+}$ ion sensor 4 , based on a coumarin platform coupled with a tetraamide receptor, can specifically detect $\mathrm{Hg}^{2+}$ ions through the ICT mechanism (Wang et al., 2006). Fluorescein-coumarin chemodosimeter $\mathbf{5}$ for 
signaling $\mathrm{Hg}^{2+}$ ions is designed based on FRET arising from the interaction between a pair of fluorophores (Ryu et al., 2010). Rhodamine-coumarin conjugate 7 was developed as a probe for $\mathrm{Hg}$ (II) ions. The fluorescence response to $\mathrm{Hg}$ (II) ions is attributed to the 1:1 complex formation between probe 7 and $\mathrm{Hg}^{2+}$ (Q.-J. Ma et al., 2010). Chemosensor 9 based on the coumarin thiosemicarbazide displays a selective fluorescence enhancement for $\mathrm{Hg}^{2+}$, which is attributed to the transformation of thiosemicarbazide unit to 1,3,4-oxadiazoles via $\mathrm{Hg}^{2+}$ induced desulfurization reaction in aqueous media (W. Ma et al., 2010). Coumarinyldithiane 11 and thiocoumarin 12 selectively sense $\mathrm{Hg}^{2+}$ also due to the $\mathrm{Hg}^{2+}$-induced desulfurization reaction. Probe 14 belongs to the turn-on class of sensors, functioning via a PET process (Voutsadaki et al., 2010).

Chemosensors $\mathbf{1 5}$ and $\mathbf{1 6}$ are not coumarin derivatives but in the presence of $\mathrm{Hg}$ (II) ions the weakly fluorescent precursor 15 can be transformed to strongly fluorescent coumarin 17 via a desulfurization-lactonization cascade reaction as shown in Fig. 2 (Jiang \& Wang, 2009). Similarly, 16 selectively senses inorganic mercury in the turn-on mode through a $\mathrm{Hg}$ (II) ionpromoted hydrolysis-cyclization reaction that leads to coumarin $\mathbf{1 7}$ as shown in Fig. 3 (Cho \& Ahn, 2010).<smiles>CCN(CC)CCCCCC(C)C</smiles>

15

almost non-fluoresent<smiles></smiles>

[<smiles>CCN(CC)c1ccc(C(C(=O)OC)(C(=O)OC)C(=O)OC)c(O)c1</smiles><smiles>CCNc1ccc2cc(C(=O)OC)c(=O)oc2c1</smiles>

17

strongly fluoresent spontaneous lactonization<smiles>CCN(CC)c1ccc2c(c1)OCC(C)(C)C2</smiles>

Fig. 2. Transformation of sensor 14 to fluorescent coumarin $\mathbf{1 6}$ via $\mathrm{Hg}$ (II)-induced desulfurization-lactonization<smiles>C=COc1cc(N(CC)CC)ccc1C=C(C(=O)OC)C(=O)OC</smiles>

Fig. 3. The reaction of probe 16 with $\mathrm{HgCl}_{2}$ 
Detection of trace amount of $\mathrm{Cu}^{2+}$ is important not only for environmental applications, but also for toxicity determination in living organs. Following the report that a new cavitand bearing four coumarin groups acts as fluorescent chemosensor for $\mathrm{Cu}^{2+}$ (Jang et al., 2006), over ten more coumarin-derived fluorescent chemosensors for $\mathrm{Cu}(\mathrm{II})$ ions have been envisaged. The structures and references of these chemical sensors are listed in Table 2.

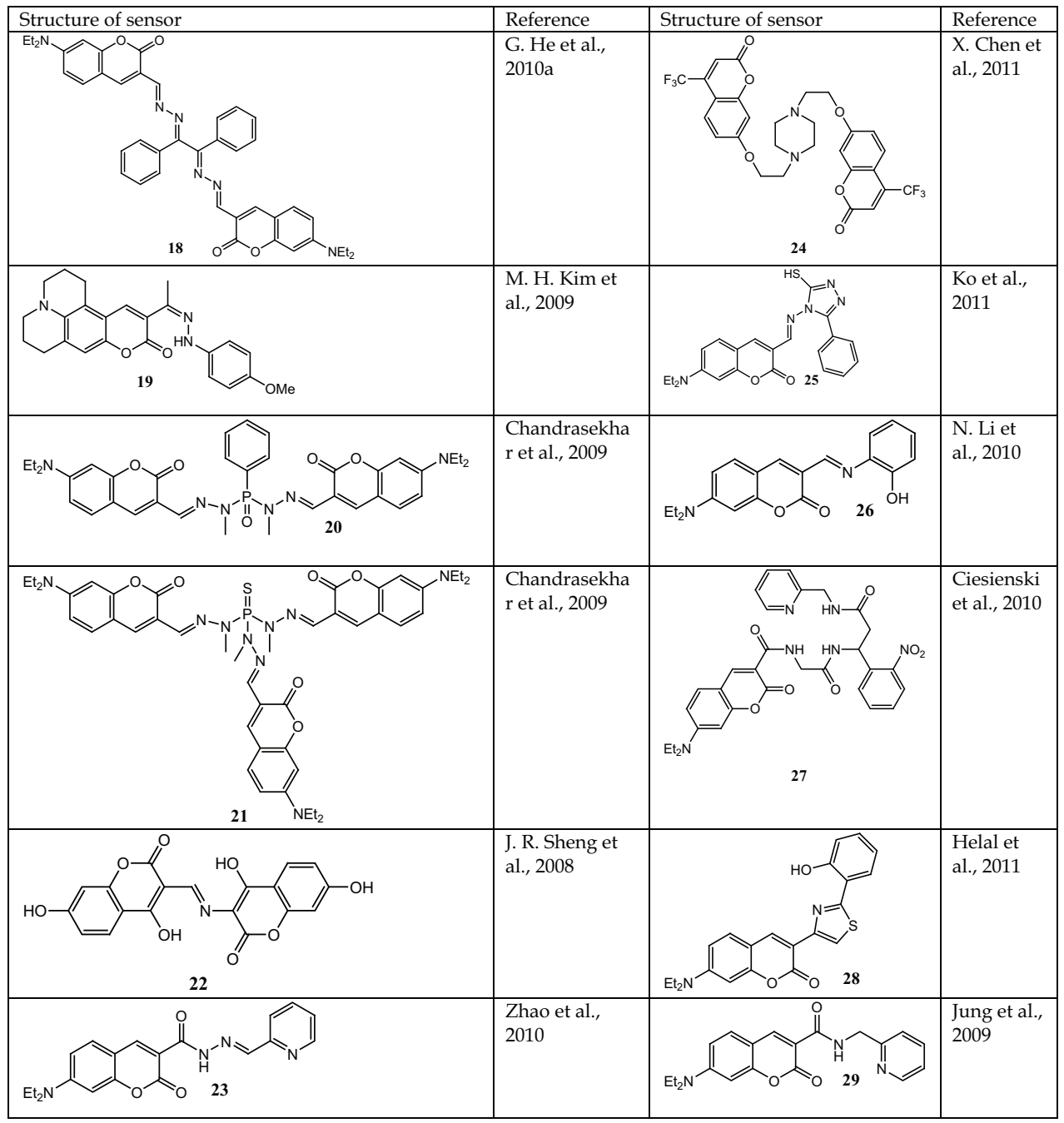

Table 2. Structures and references of coumarin-derived chemosensors for $\mathrm{Cu}(\mathrm{II})$ ions

A turn-on fluorescent probe $\mathbf{1 8}$ for $\mathrm{Cu}^{2+}$ is presented by incorporating coumarin fluorophores within the benzyl dihydrazone moiety. It is among the brightest $\mathrm{Cu}^{2+}$ binding sensors in aqueous media reported to date (G. He et al., 2010a). Coumarin 19 is a highly effective turn-on fluorescent sensor that is catalytically hydrolyzed by $\mathrm{Cu}^{2+}$ leading to a 
large increase in the fluorescence intensity (M. H. Kim et al., 2009). Studies on interaction of phosphorus-supported multidentate coumarin-containing fluorescent sensors 20 and 21 with various transition metal ions reveal substantial fluorescence enhancement upon interaction with $\mathrm{Cu}^{2+}$ enabling a selective detection mechanism for $\mathrm{Cu}^{2+}$ (Chandrasekhar et al., 2009). Biscoumarin 22 linked by a $\mathrm{C}=\mathrm{N}$ double bond is highly sensitive and selective to $\mathrm{Cu}^{2+}$ and the fluorescent sensing mechanism is based on $\mathrm{C}=\mathrm{N}$ isomerization (J. R. Sheng et al., 2008). Coumarin probe $\mathbf{2 3}$ is highly selective for $\mathrm{Cu}^{2+}$ over biologically relevant alkali metals, alkaline earth matals and the first row transition metals due to the formation of a 1:2 complex between $\mathrm{Cu}^{2+}$ and 23 (Zhao et al., 2010). Fluorescent biscoumarin 24 linked by a piperazine unit shows high selectivity towards $\mathrm{Cu}^{2+}$ (Chen et al., 2011). Rationally designed iminocoumarin fluorescent sensor 25 displays high selectivity for $\mathrm{Cu}^{2+}$ over a variety of competing metal ions in aqueous solution with a significant fluorescence increase (Ko et al., 2011). Nonfluorescent coumarin derivative $\mathbf{2 6}$ is synthesized as an efficient turn-on fluorescent chemodosimeter for $\mathrm{Cu}^{2+}$ in water. Mechanism studies suggest that $\mathbf{2 6}$ forms a complex with $\mathrm{Cu}^{2+}$ in a 1:2 metal-to-ligand ratio, and a 50-fold fluorescence enhancement is observed when the complex simultaneously undergoes $\mathrm{Cu}^{2+}$-promoted hydrolysis $(\mathrm{N}$. Li et al., 2010). Sensor 27 relies on a coumarin-tagged ligand that selectively binds $\mathrm{Cu}^{2+}$ over other biometals to induce fluorescence quenching, which is subsequently relieved upon UV irradiation to provide the turn-on response (Ciesienski et al., 2010). For chemosensor 28 the mechanism of fluorescence is based on ICT, which is modified by the introduction of an electron-donating diethylamino group making it chromogenic and increasing the binding affinity (Helal et al., 2011). Coumarin 29 appending 2-picolylamide enables efficient tridentate complexation for $\mathrm{Cu}(\mathrm{II})$ in preference to a variety of other common heavy and toxic metal ions (Jung et al., 2009).

Owing to the important role of zinc, the second most abundant transition metal in the human body, more and more attention has been paid to development of $\mathrm{Zn}^{2+}$-specific chemosensors including coumarin-derived fluorescent chemosensors for $\mathrm{Zn}(\mathrm{II})$ ions, the structures and references of which are listed in Table 3.

Study on the sensory capabilities of two novel di(2-picolyl)amine (DPA)-substituted coumarins $\mathbf{3 0}$ and $\mathbf{3 1}$ shows that the variation of the point of attachment of the DPA group to the coumarin framework controls their sensing behavior: the 4-subsituted system $\mathbf{3 0}$ is a chelation-enhanced fluorescence (CHEF)-type sensor which shows a significant increase in fluorescence intensity upon $\mathrm{Zn}^{2+}$ binding, whereas the 3-substituted coumarin 31 is a ratiometric sensor (N. C. Lim \& Brückner, 2004). Coumarin Schiff-base 32 acts as a turn-on fluorescent chemosensor for $\mathrm{Zn}(\mathrm{II})$ ions (H. Li et al., 2009) and 33 does not show any twophoton activity in the wavelength range $760-860 \mathrm{~nm}$ but in the presence of $\mathrm{Zn}$ (II) 33 exhibits large two-photon absorption as well as emission in the same wavelength range (Ray et al., 2010). Another coumarin Schiff-base 43 is a highly sensitive and selective fluorescent probe for $\mathrm{Zn}^{2+}$ in tetrahydrofuran (THF) (Yan et al., 2011). In coumarin Schiff-base 34 the fluorescence quenching is dominant because of the nitrogen lone pair orbital contribution to the excitation. Upon $\mathrm{Zn}^{2+}$ coordination 34 shows a significant fluorescence enhancement due to the blocking of the nitrogen lone pair orbital by metal coordination (Jung et al., 2010). A series of coumarin-based fluorescent probes 35-38 for detecting $\mathrm{Zn}^{2+}$ with high affinities show the ratiometric fluorescent properties (Mizukami et al., 2009). Another series of coumarin-derived chemosensors 39-42 belong to the CHEF-type and have been showed to 


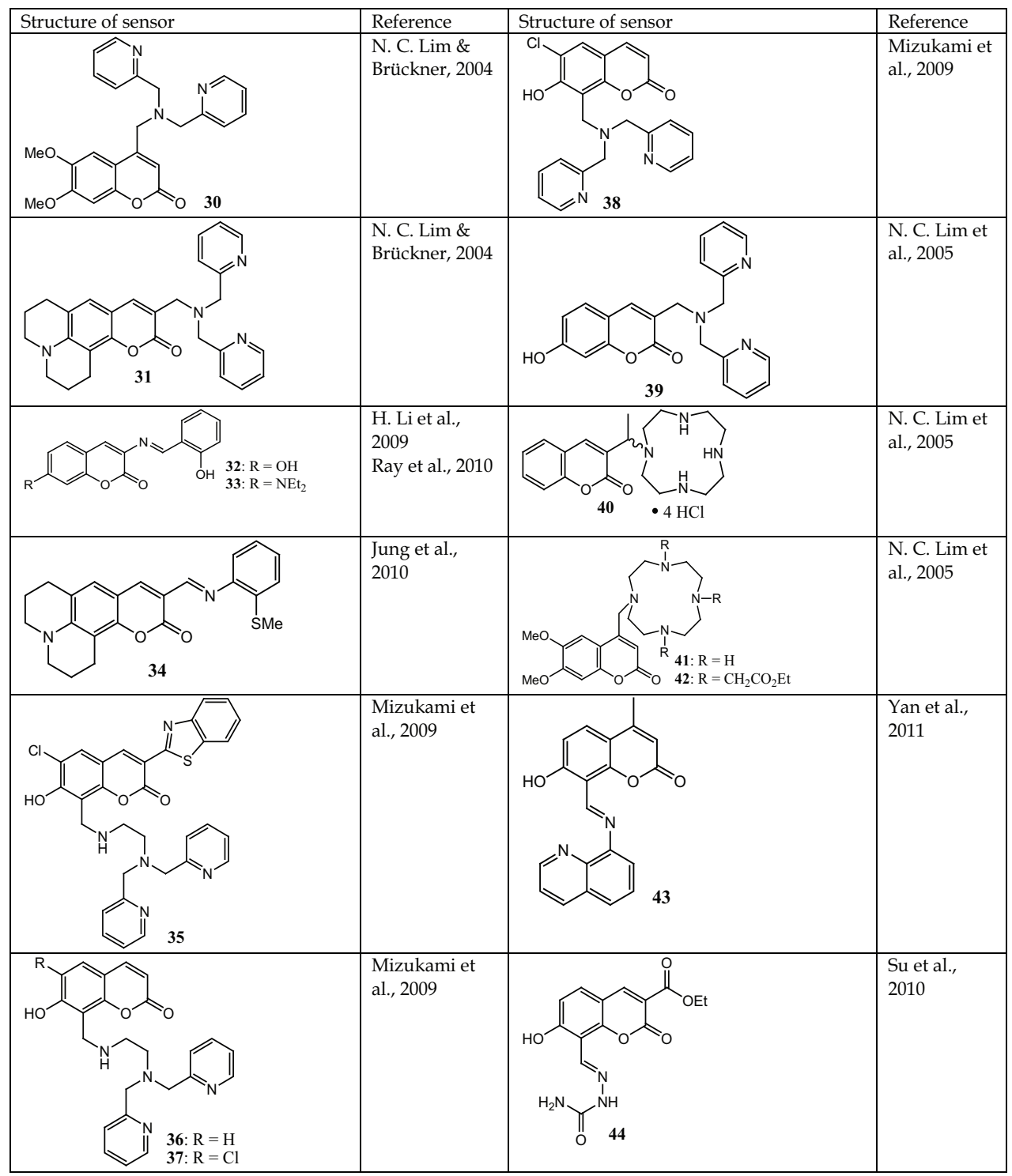

Table 3. Structures and references of coumarin-derived chemosensors for Zn(II) ions

be competent for detecting zinc pools in cultured rat pituitary (GH3) and hepatoma (H4IIE) cell lines (N. C. Lim et al., 2005). Coumarin 44 is a fluorescent sensor for $\mathrm{Zn}^{2+}$ and exhibits lower background fluorescence due to intramolecular PET but upon mixing with $\mathrm{Zn}^{2+}$ in aqueous ethanol, a turn-on fluorescence emission is observed (Su et al., 2010). Recently it was reported that a biscoumarin linked by bi-thiazole acted as a colorimetric receptor selectively for $\mathrm{Zn}^{2+}$ (Upadhyay \& Mishra, 2010). 
Structures of several coumarin-derived fluorescent chemosensors for iron(III) are shown in Fig. 4. Squarate hydroxamate-coumarin conjugate 45 is designed as a CHEF-type sensor for $\mathrm{Fe}(\mathrm{III})$. Due to a PET process, 45 possesses a low fluorescence yield but upon exposure of $\mathbf{4 5}$ to $\mathrm{Fe}(\mathrm{III})$, an irreversible 9-fold fluorescence intensity increase is observed as the result of an oxidation/hydrolysis reaction (N. C. Lim et al., 2009). Coumarin derivative 46 exhibits high selectivity for $\mathrm{Fe}^{3+}$ and the selectivity is not affected by the presence of representative alkali metals, alkali earth metals and other transition metal salts (Yao $t$ al., 2009). Mugineic acidcoumarin derivative 47 synthesized by click chemistry acts as a fluorescent probe for $\mathrm{Fe}^{3+}$ (Namba et al., 2010). Coumarin-based hexadentate fluorescent probes for selective quantification of iron(III) have also been designed and synthesized (Y. M. Ma \& Hider, 2009).
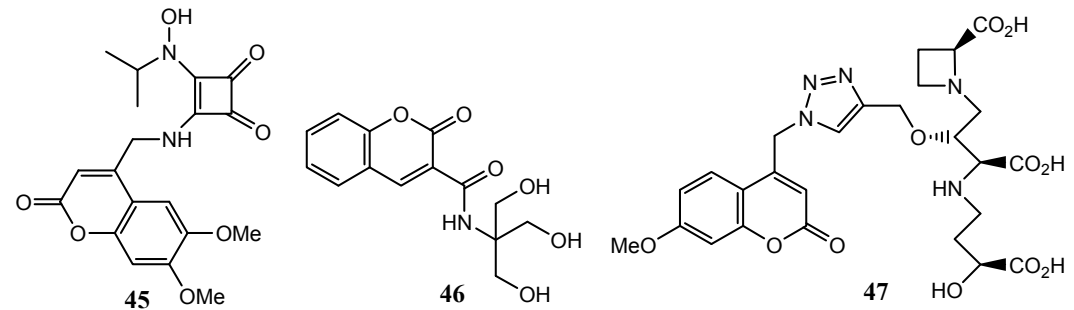

Fig. 4. Structures of coumarin-derived fluorescent chemosensors for iron(III) ion

Structures of coumarin-derived fluorescent chemosensors for $\mathrm{Mg}$ (II) are shown in Fig. 5 . Coumarin-based two-photon probe $\mathbf{4 8}$ is developed for the detection of free $\mathrm{Mg}^{2+}$ ions in living cells and living tissues. The probe can be excited by $880 \mathrm{~nm}$ laser photons, emits strong twophoton excited fluorescence in response to $\mathrm{Mg}^{2+}$ ions (H. M. Kim et al., 2007). Coumarin Schiffbase 49, without two-photon activity in the wavelength range 760-860 nm, exhibits large twophoton absorption as well as emission in the presence of $\mathrm{Mg}^{2+}$ (Ray et al., 2010). Coumarinbased chromoionophore 50 implemented in a transparent membrane can be used as an optical one-shot sensor for $\mathrm{Mg}^{2+}$ (Capitán-Vallvey, 2006). Two coumarin salen-based sensors 51 and 52 exhibit a pronounced fluorescence enhancement response toward $\mathrm{Mg}^{2+}$ in the presence of $\mathrm{Na}^{+}$ as a synergic trigger (Dong et al., 2011). Coumarin-derived fluorescent molecular probes 53 and $\mathbf{5 4}$ can be used for highly selective detection of $\mathrm{Mg}^{2+}$ versus $\mathrm{Ca}^{2+}$ by means of monitoring the absorption and fluorescence spectral change (Suzuki et al., 2002).<smiles>O=C(O)c1cc2ccc3cc([N+](=O)[O-])ccc3c2oc1=O</smiles>

48

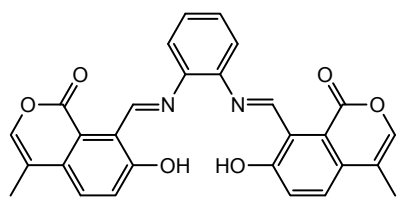

51

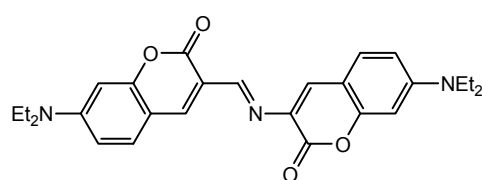

49

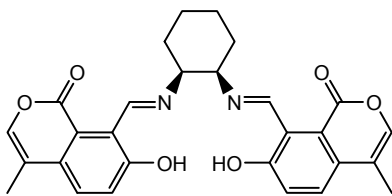

52<smiles>CCNc1ccc2cc(C(=O)c3ccc4c(c3)OCCO4)c(=O)oc2c1</smiles>

50<smiles></smiles>

Fig. 5. Structures of coumarin-derived fluorescent chemosensors for $\mathrm{Mg}$ (II) ion 
Fig. 6 shows the structures of coumarin-derived fluorescent chemosensors for Ag(I). A highly sensitive and selective fluorescent chemosensor 55 for $\mathrm{Ag}^{+}$based on a coumarin-Se $\mathrm{N}_{2}$ chelating conjugate is developed. Due to inhibiting a PET quenching pathway, a fluorescent enhancement of 4-fold is observed under the binding of the $\mathrm{Ag}^{+}$cation to 55 with a detection limit down to the 10-8 $\mathrm{M}$ range (S. Huang et al., 2011). Coumarin 56 and 57 are highly silver ion selective fluorescence ionophores (Sakamoto et al., 2010). By a microwave-assisted dual click reaction, fluorogenic 3-azidocoumarin can be rapidly introduced onto a 3,4-dipropargylglucoor galactosyl scaffold with restored fluorescence. Subsequent desilylation leads to water soluble sugar-bis-triazolocoumarin conjugates which are applicable toward selective $\mathrm{Ag}^{+}$ detection in aqueous media via fluorescence spectroscopy (X.-P. He et al., 2011).<smiles></smiles><smiles>CCSCCN(CCSCC)Cc1c(O)ccc2c(C)cc(=O)oc12</smiles><smiles>CSCCSCCN(CCSC)Cc1c(O)ccc2c(C)cc(=O)oc12</smiles>

Fig. 6. Structures of coumarin-derived fluorescent chemosensors for silver(I) ion

Structures of coumarin-derived fluorescent chemosensors for lead(II) are shown in Fig. 7. Fluorescent chemosensor 58 based on a coumarin-crown ether conjugate exhibits a high affinity and selectivity for $\mathrm{Pb}^{2+}$ (C.-T. Chen \& W.-P. Huang, 2002). Coumarin dyes 59-61 seem to fulfill most of the criteria required for intracellular lead indicators, as they exhibit high selectivity for $\mathrm{Pb}^{2+}$ (Roussakis et al., 2008). Ion competition studies and fluorescence experiments show that a fullerene-coumarin dyad is selective for $\mathrm{Pb}^{2+}$ complexation (Pagona et al., 2010).<smiles>CCNc1ccc2cc(C(=O)c3ccc(N4CCOCCOCCOCCOCC4)cc3)c(=O)oc2c1</smiles><smiles>[X]c1ccccc1[X]</smiles>

Fig. 7. Structures of coumarin-derived fluorescent chemosensors for lead(II) ion

Apart from the above-mentioned metal ions, coumarin-derived fluorescent chemosensors have been used for detection of other metal ions including $\mathrm{Cd}^{2+}$ (Taki et al., 2008), $\mathrm{Al}^{3+}$ (Maity \& Govindaraju, 2010), and $\mathrm{Cr}^{3+}$ (Hu et al., 2011). Some coumarin-derived fluorescent chemosensors exhibit simultaneous sensitivity toward two or more different metal ions, e.g. $\mathrm{Cu}$ (II) and $\mathrm{Hg}$ (II) based on FRET mechanism (G. He et al., 2010b) or via selective anioninduced demetallation (Lau et al., 2011), $\mathrm{Cu}^{2+}$ and $\mathrm{Ni}^{2+}$ (H. Li et al., 2011), $\mathrm{Ni}^{2+}$ and $\mathrm{Zn}^{2+}$ (Chattopadhyay et al., 2006), $\mathrm{Ni}^{2+}$ and $\mathrm{Co}^{2+}$ (Lin et al., 2009), $\mathrm{Ca}^{2+}$ and $\mathrm{Mg}^{2+}$ (Suresh \& Das, 2009), $\mathrm{Na}^{+}$and $\mathrm{K}^{+}$(Ast et al., 2011), $\mathrm{Hg}^{2+}$ and $\mathrm{Ag}^{+}$(Tsukamoto et al., 2011), $\mathrm{Cu}^{2+} / \mathrm{Ni}^{2+} / \mathrm{Cd}^{2+}$ (Lin et al., 2008), $\mathrm{Zn}^{2+} / \mathrm{Cd}^{2+} / \mathrm{Pb}^{2+}$ (Kulatilleke et al., 2006), or $\mathrm{Ni}^{2+} / \mathrm{Pd}^{2+} / \mathrm{Ag}^{+}$(Santos et al., 2009). 


\subsection{Coumarin-derived fluorescent chemosensors for anions}

Development of highly efficient chemosensors for cyanide is of extreme significance due to the detrimental aspect of cyanide. Much attention has been paid to the utilization of fluorescent methods for the detection of cyanide. Several coumarin-derived fluorescent chemosensors for $\mathrm{CN}$ - have been reported, the structures of which are shown in Fig. 8.

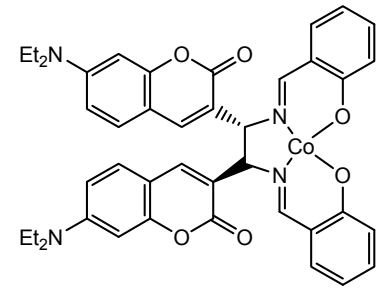

62<smiles>CCNc1ccc2cc(/C=C/[N+](=O)[O-])c(=O)oc2c1</smiles>

65

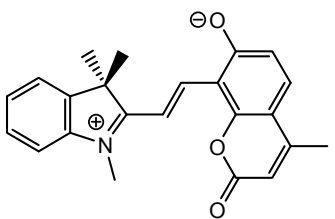

63<smiles>CCNc1ccc2cc(C=O)c(=O)oc2c1</smiles>

66<smiles>CCCCn1c(/C=C/c2cc3cc4c5c(c3oc2=O)CCCN5CCC4)[n+](CCC)c2ccccc21</smiles>

64<smiles>O=Cc1c(O)ccc2ccc(=O)oc12</smiles>

67

Fig. 8. Structures of coumarin-derived fluorescent chemosensors for cyanide

Cobalt(II)-coumarinylsalen complex 62 exhibits selective and tight binding to a cyanide anion and displays a significant fluorescence enhancement upon the addition of cyanide owing to the interruption of PET from the coumarin fluorophore to the cobalt(II)-salen moiety (J. H. Lee et al., 2010). Coumarin-spiropyran conjugate 63 is a highly sensitive chemosensor for $\mathrm{CN}^{-}$and shows a CN--selective fluorescence enhancement under UV irradiation (Shiraishi et al., 2011). An indole conjugated coumarin 64 for $\mathrm{KCN}$ chemodosimeter displays considerable dual changes in both absorption (blue-shift) and emission (turn-on) bands exclusively for KCN. The fluorescence enhancement of the $64-\mathrm{KCN}$ is mainly due to blocking of the ICT process $(\mathrm{H}$. J. Kim et al., 2011). Doubly activatived coumarin 65 acts as a colorimetric and fluorescent chemodosimeter for cyanide (G.-J. Kim \& H.-J. Kim, 2010a). A simple aldehyde-functionalized coumarin 66 has been utilized as a doubly activated Michael acceptor for cyanide (G.-J. Kim \& H.-J. Kim, 2010b). Coumarin-based fluorescent chemodosimeter 67 with a salicylaldehyde functionality as a binding site has shown selectivity for cyanide anions over other anions in water at biological pH (K.-S. Lee et al., 2008a).

Recognition and detection of fluoride, the smallest anion with unique chemical properties is of growing interest. Several coumarin-derived fluorescent chemosensors for $\mathrm{F}^{-}$have been developed, the structures of which are shown in Fig. 9.

Coumarin derivative 68 has been developed as a fluorescent probe for detection of $\mathrm{F}^{-}$ion in water and bioimaging in A549 human lung carcinoma cells (S. Y. Kim et al., 2009). Coumarin 69 is a simple, highly selective, and sensitive chemosensor for fluoride anions in organic and aqueous media based on the specific affinity of fluoride anion to silicon (Sokkalingam \& Lee, 2011). Coumarin-derived chemosensor 70 shows an obvious color change from yellow to blue upon addition of $\mathrm{F}^{-}$ion with a large red shift of $145 \mathrm{~nm}$ in acetonitrile (Zhuang et al., 2011). Coumarin-based hydrazone $\mathbf{7 1}$ is an ICT probe for fluoride in aqueous medium (Upadhyay et al., 2010a). Coumarin-based system 72 has been developed as a novel turn-on fluorescent and colorimetric sensor for fluoride anions (J. Li et al., 2009). 
<smiles>CCNc1ccc2cc(/C=N/Nc3ccc([N+](=O)[O-])cc3)c(=O)oc2c1</smiles>

Fig. 9. Structures of coumarin-derived fluorescent chemosensors for F- ion

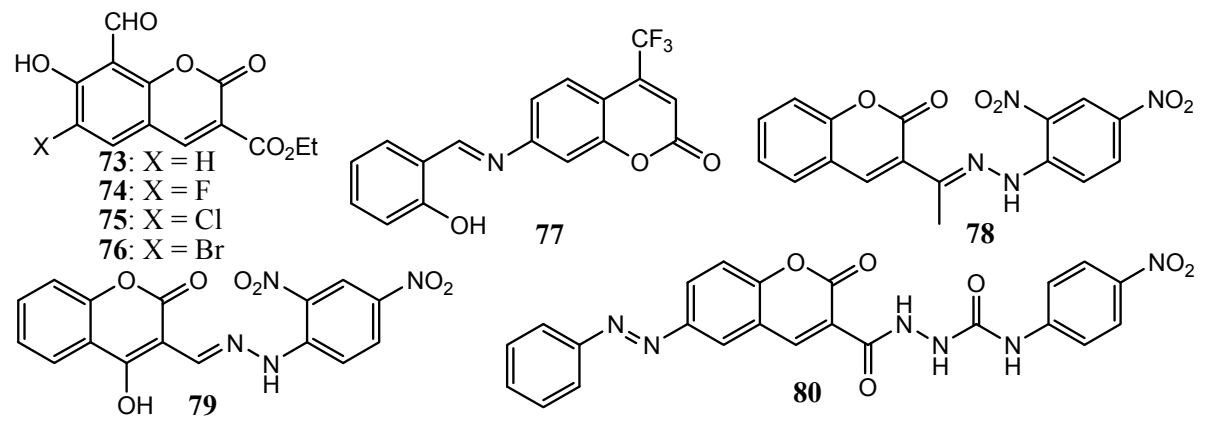

Fig. 10. Structures of coumarin-derived fluorescent chemosensors for anions other than $\mathrm{CN}^{-}$ and F-

Structures of coumarin-derived fluorescent chemosensors for detection of anions other than $\mathrm{CN}^{-}$and $\mathrm{F}^{-}$have been shown in Fig. 10. Coumarin-based fluorescent probes 73-76 with salicylaldehyde functinoality as recognition unit have been developed for selective detection of bisulfite anions in water (K. Chen et al., 2010). Coumarin Schiff-base 77 is a highly selective and sensitive turn-on fluorogenic probe for detection of $\mathrm{HSO}_{4}^{-}$ions in aqueous solution (H. J. Kim et al., 2009b). Coumarin-based hydrazone 78 acts as an ICT probe for detection of acetate, benzoate, and dihydrogenphosphate (Upadhyay et al., 2010b). Another coumarin-based hydrazone $\mathbf{7 9}$ has been utilized as both a colorimetric and ratiometric chemosensor for acetate and a selective fluorescence turn-on probe for iodide (Mahapatra et al., 2011). Compound $\mathbf{8 0}$ is a colorimetric and fluorescence anion sensor with the urea group as binding site and the coumarin moiety as signal unit. The sensor displays significant fluorescence enhancement response to anions such as acetate, because of complex formation (Shao, 2010). Coumarin-derived fluorescent chemosensors have also been used for detection of pyrophosphate (S. K. Kim et al., 2009), $\mathrm{H}_{2} \mathrm{PO}_{4}^{-}$and $\mathrm{PhPO}_{3} \mathrm{H}^{-}$(K. Choi \& Hamilton, 2001), and multiple anions including pyrophosphate, citrate, ATP and ADP (Mizukami et al., 2002). A new Zn ${ }^{I I}-2,2^{\prime}: 6^{\prime}, 2^{\prime \prime}$-terpyridine complex, derivatized with a coumarin moiety, acts as a fluorescent chemosensor for different biologically important phosphates like PPi, AMP and ADP in mixed aqueous media (Das et al., 2011). A strapped calix[4]pyrrole-coumarin conjugate has been developed as a fluorogenic anions $\left(\mathrm{Cl}^{-}, \mathrm{Br}^{-}\right.$and $\left.\mathrm{AcO}^{-}\right)$receptor modulated by cation and anion binding (Miyaji et al., 2005). 


\subsection{Coumarin derivatives as fluorescent probes of $\mathrm{pH}$}

Structures of coumarin-derived fluorescent chemosensors for sensing $\mathrm{pH}$ are shown in Fig. 11. Several iminocoumarin (81) derivatives 82-84 have been synthesized as a new type of fluorescent $\mathrm{pH}$ indicator. The indicators possess moderate to high brightness, excellent photostability and compatibility with light-emitting diodes. The indicators can be covalently immobilized on the surface of amino-modified polymer microbeads which in turn are incorporated into a hydrogel matrix to afford novel $\mathrm{pH}$-sensitive materials. When a mixture of two different microbeads is used, the membranes are capable of optical pH sensing over a very wide range comparable to the dynamic range of the glass electrode ( $\mathrm{pH}$ 1-11) (Vasylevska et al., 2007). Coumarin derivative 85 containing piperazine and imidazole moieties has been developed as a fluorophore for hydrogen ions sensing. The fluorescence enhancement of the sensor with an increase in hydrogen ions concentration is based on the hindering of PET from the piperazinyl amine and the imidazolyl amine to the coumarin fluorophore by protonation. The sensor 85 has a novel molecular structure design of fluorophore-spacer-receptor(1)receptor(2) format and therefore is proposed to sense two range of $\mathrm{pH}$ from 2.5 to 5.5 and from 10 to 12 instead of sensing one $\mathrm{pH}$ range (Saleh et al., 2008). By using rational molecular design, two molecular functions, the transport by vesicular monoamine transporter (VMAT) and ratiometric optical $\mathrm{pH}$ sensing, have been integrated to develop ratiometric $\mathrm{pH}$-responsive fluorescent false neurotansmitter (FFN) probes (M. Lee et al., 2010). A FRET sensor with a donor and an acceptor attached to each end of $\mathrm{pH}$-sensitive polysulfoamides exhibits an instantaneous conformation change from coil to globule at a specific $\mathrm{pH}$, which results in the drastic on-and-off FRET efficiency. To detect a specific $\mathrm{pH}$ region, sulfadimethoxine and sulfamethizole are selected among various sulfonamides since their $\mathrm{p} K_{\mathrm{a}}$ values are in the physiological $\mathrm{pH}$. For tuning the emission color arising from FRET, 7-hydroxy-4bromomethylcoumarin and coumarin 343 are used as a FRET donor and an acceptor, respectively, for a blue-to-green FRET sensor (Hong \& Jo, 2008).<smiles>CCNc1ccc2cc(-c3nc4ccccc4[nH]3)c(=N)oc2c1</smiles>

81<smiles></smiles><smiles>CCN(CC)c1ccc2cc3c(nc2c1)OC(=O)C(c1ccc(O)cc1O)N3c1ccccc1</smiles>

82<smiles>CCNc1ccc2c(c1)OC1=NC(c3ccc(O)c(C(=O)O)c3)n3c(nc4ccccc43)C1=C2</smiles>

83<smiles>CCc1nc([N+](=O)[O-])c(N2CCN(Cc3cc(=O)oc4cc(OC)ccc34)CC2)n1Cc1ccccc1</smiles>

Fig. 11. Structures of coumarin-derived fluorescent chemosensors for sensing $\mathrm{pH}$

\subsection{Coumarin-derived fluorescent chemosensors for thiols}

Biothiols such as cysteine (Cys), homocysteine (Hcy), and glutathione (GSH) are of great significance because they are involved in myriad vital cellular processes including redox homeostasis and cellular growth. Alteration of the cellular biothiols is also implicated in 
cancer and AIDS. Study on fluorescent and colorimetric probes for detection of thiols has received much attention and many coumarin-derived fluorescent chemosensors for detection of thiols have been reported. The structures of these chemical sensors are shown in Fig. 12.

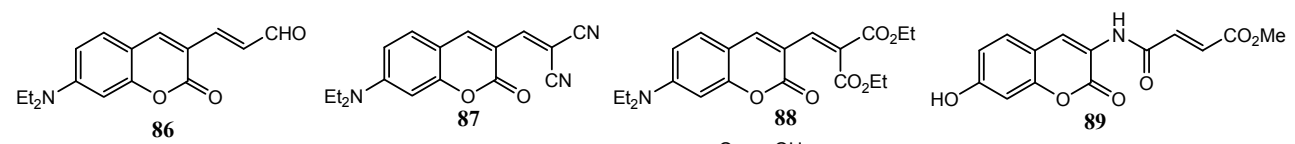

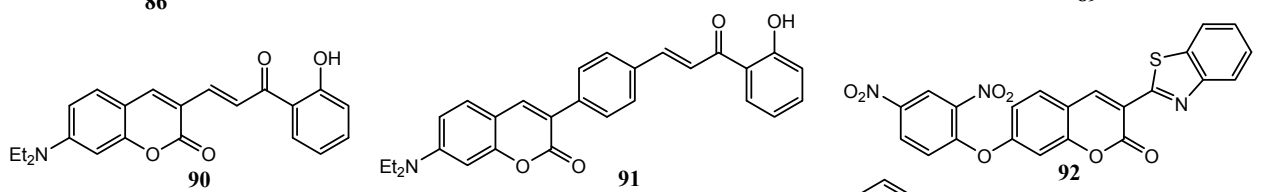<smiles></smiles><smiles>Cc1cc(=O)oc2cc(S)ccc12</smiles>

93

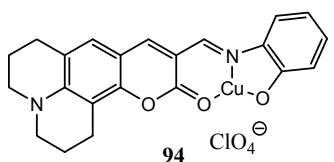<smiles>CCCNc1ccc2cc(C(=O)CBr)c(=O)oc2c1</smiles>

Fig. 12. Structures of coumarin-derived chemosensors for detection of thiols

Generally detection of thiols by optical probes is based on two features of thiols, their strong nucleophilicity and high binding affinity toward metal ions. Accordingly, most of the fluorescent probes for thiols are in fact chemodosimeters, which involve specific reactions between probes and thiols, such as Michael addition, cyclization with aldehyde (or ketone), cleavage of disulfide by thiols, metal complexes-displace coordination, demetalization from $\mathrm{Cu}$-complex, thiolysis of dinitrophenyl ether, and Staudinger ligation. For instance, detection of thiols by chemosensors 87-91 and 93 involves Michael addition between the probes and thiols. For sensors 67 (Fig. 8), 86 and 98, cyclization reactions occur between the sensors and thiols in the detection process. Coumarin 86 is a ratiometric fluorescent probe for specific detection of Cys over Hcy and GSH based on the drstic distinction in the kinetic profiles (Yuan et al., 2011). Nonfluorescent coumarin-malonitrile conjugate 87 can be transformed into a strongly fluorescent molecule through the Michael addition and thus exhibits a highly selective fluorescence response toward biothiols including Cys, Hcy and GSH with micromolar sensitivity (Kwon et al., 2011). Similarly, nonfluorescent 88 displays a highly selective fluorescence enhancement with thiols and has been successfully applied to thiols determination in intracellular, in human urine and blood samples (Zuo et al., 2010). Coumarin 89 has been developed as a water-soluble, fast-response, highly sensitive and selective fluorescence thiol quantification probe (Yi et al., 2009). Compound 90 (G.-J. Kim et al., 2011) and 91 (S. Y. Lim et al., 2011) with a hydrogen bond act as highly selective ratiometric fluorescence turn-on probes for GSH. Structure 92 has been judiciously designed and synthesized as a new type of selective benzenethiol fluorescent probe based on the thiolysis of dinitrophenyl ether (Lin et al., 2010a). Coumarin-based chemodosimeter 93 effectively and selectively recognizes thiols based on a Michael type reaction, showing a preference for Cys over other biological materials including Hcy and GSH (Jung et al., 
2011a). Iminocoumarin-Cu(II) ensemble-based chemodosimeter 94 sensitively senses thiols followed by hydrolysis to give a marked fluorescence enhancement over other amino acids based on demetalization from Cu-complex (Jung et al., 2011b). Nonfluorescent coumarinphosphine dye 95 reacts with S-nitrosothiols (RSNOs) to form a fluorescent coumarin derivative and thus may be used as a tool in the detection of RSNOs. The reaction mechanism is similar to the well-known Staudinger ligation (Pan et al., 2009). 7-Mercapto-4methylcoumarin 96 is a reporter of thiol binding to the CdSe quantum dot surface (González-Béjar et al., 2009). Coumarin-derived complex 97 has been developed as a reversible fluorescent probe for highly selective and sensitive detection of mercapto biomolecules such as Cys, Hcy and GSH (J. Wu et al., 2011). A simple coumarin derivative 98 is the first fluorescence turn-on probe for thioureas by the double functional group transformation strategy. The probe exhibits high sensitivity and selectivity for thioureas over other structurally and chemically related species including urea and thiophenol (Lin et al., 2010b). The simple coumarin sensor 67 (Fig. 8) has shown fluorescence selectivity for not only cyanide anions but also Hcy and Cys in water (K.-S. Lee et al., 2008b). A new coumarincontaining zinc complex has been developed as a colorimetric turn-on and fluorescence turn-off sensor which shows high selectivity for hydrogen sulfide in the presence of additional thiols like Cys or GSH (Galardon et al., 2009).

\subsection{Coumarin-derived fluorescent chemosensors for $\mathrm{H}_{2} \mathrm{O}_{2}, \mathrm{O}_{2}$, hydroxyl radicals or chemical warfare agents}

Structures of coumarin-derived fluorescent chemosensors for hydrogen peroxide, oxygen, hydroxyl radicals or chemical warfare agents are shown in Fig. 13. Water-soluble umbelliferone-based fluorescent probe 99 shows very large increase (up to 100-fold) in fluorescent intensity upon reaction with hydrogen peroxide, and good selectivity over other reactive oxygen species (Du et al., 2008). Another water-soluble fluorescent hydrogen peroxide probe $\mathbf{1 0 0}$ based on a 'click' modified coumarin fluorophore shows significant intensity increases (up to fivefold) in near-green fluorescence upon reaction with $\mathrm{H}_{2} \mathrm{O}_{2}$, and good selectivity over other reactive oxygen species (Du Ý et al., 2010). More recently a simple and highly sensitive fluorometric method was proposed for the determination of $\mathrm{H}_{2} \mathrm{O}_{2}$ in milk samples. In this method, nonfluorescent coumarin was oxidized to highly fluorescent 7-hydroxycoumarin by hydroxyl radicals generated in a Fenton reaction, and the oxidation product had strong fluorescence with a maximum intensity at $456 \mathrm{~nm}$ and could be used as a fluorescent probe for $\mathrm{H}_{2} \mathrm{O}_{2}$ (Abbas et al., 2010). Thiazo-coumarin ligand directly cyclometallated $\mathrm{Pt}(\mathrm{II})$ complex 101 has been used for luminescent $\mathrm{O}_{2}$ sensing (W. Wu et al., 2011). A hybrid coumarin-cyanine platform 102 has been developed as the first ratiometric fluorescent probe for detection of intracellular hydroxyl radicals (Yuan et al., 2010). More recently a coumarin-neutral red (CONER) nanoprobe was developed for detection of hydroxyl radical based on the ratiometric fluorescence signal between 7-hydroxy coumarin 3-carboxylic acid and neutral red dyes. Biocompatible poly lactide-co-glycolide nanoparticles containing encapsulated neutral red were produced using a coumarin 3carboxylic acid conjugated poly(sodium $\mathrm{N}$-undecylenyl-Ne-lysinate) as moiety reactive to hydroxyl radicals. The response of the CONER nanoprobe was dependent on various parameters such as reaction time and nanoparticle concentration. The probe was selective for hydroxyl radicals as compared with other reactive oxygen species including $\mathrm{O}_{2}{ }^{\bullet}-\mathrm{H}_{2} \mathrm{O}_{2}$, ${ }^{1} \mathrm{O}_{2}$ and $\mathrm{OCl}^{-}$(Ganea et al., 2011). 
The current rise in international concern over criminal terorist attacks using chemical warfare agents has brought about the need for reliable and affordable detection methods of toxic gases. One of the applicable technologies is the design of fluorogenic chemosensors for the specific detection of nerve agents (Royo et al., 2007). A coumarin oximate 103 has been developed for detection of chemical warfare simulants based on the PET mechanism that gives an "off-on" fluorescent response with a half-time of approximately $50 \mathrm{~ms}$ upon phosphorylation of a reactive oximate functionality (Wallace et al., 2006). Coumarin-derived hydroxy oxime 104 serves as a nerve agent sensor based on the reaction of $\beta$-hydroxy oxime with organophosphorus agent mimics (Dale \& Rebek, 2009). A FRET approach towards potential detection of phosgene has been developed as shown in Fig. 14. When both coumarins 105 and 106 are mixed together with triphosgene in the presence of $\mathrm{Et}_{3} \mathrm{~N}$ in $\mathrm{CHCl}_{3}$, hybrid urea $\mathbf{1 0 7}$ forms in a statistical yield. Significant fluorescence enhancement is detected which is particularly important since the acceptor unit alone does not emit under the same condition. The fluorescence increase is obviously due to the formation of urea 107. Simultaneously, the fluorescence from the donor unit decreases due to the quenching, indicating that efficient energy transfer takes place from the donor to the acceptor. This system is selective, since other gases/agents rarely can serve for cross-linking (Zhang \& Rudkevich, 2007).<smiles>CC1(C)OB(c2ccc3ccc(=O)oc3c2)OC1(C)C</smiles><smiles>CC1(C)OB(c2ccc3cc(-n4cc(-c5ccccc5)nn4)c(=O)oc3c2)OC1(C)C</smiles><smiles></smiles><smiles>CCCCc1c(C=N)c(=O)oc2cc(NCC)ccc12</smiles><smiles>N=Cc1c(O)ccc2ccc(=O)oc12</smiles>

Fig. 13. Structures of coumarin-derived fluorescent sensors for $\mathrm{H}_{2} \mathrm{O}_{2}, \mathrm{O}_{2}$, hydroxyl radicals or chemical warfare agents

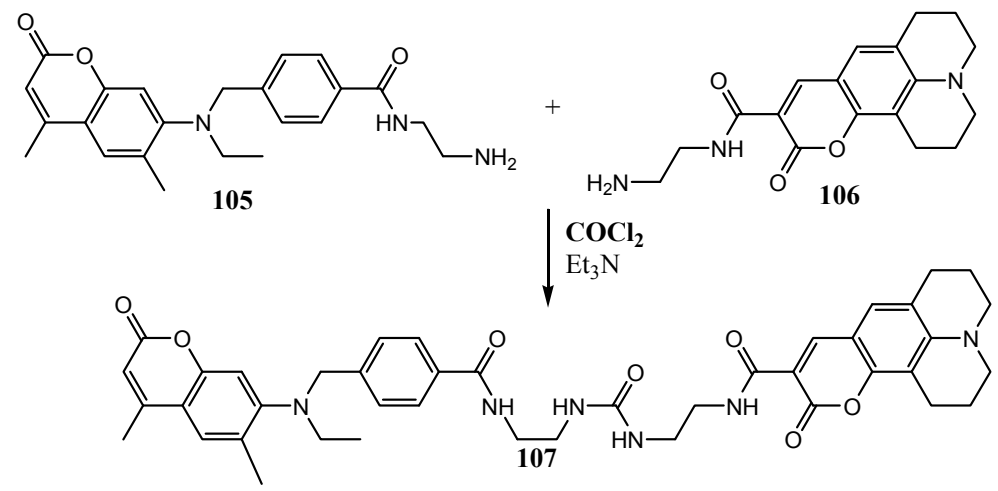

Fig. 14. Coumarins 105 and 106 react with phosgene to form urea 107 


\subsection{Coumarin-derived fluorescent chemosensors for amines, amino acids or other organic compounds}

Structures of coumarin-derived fluorescent chemosensors for amines, amino acids or other organic compounds are shown in Fig. 15. Butyl-subsituted coumarin aldehyde $\mathbf{1 0 8}$ is an excellent chemosensor for detection of amines and unprotected amino acids in aqueous conditions by formation of highly fluorescent iminium ions (Feuster \& Glass, 2003). Boronic acid-containing coumarin aldehyde $\mathbf{1 0 9}$ binds to primary catecholamines with good affinity and acts as an effective colorimetric sensor for dopamine and norepinephrine with excellent selectivity over epinephrine, amino acids, and glucose. In the fluorescence manifold, sensor 109 responds differentially to catechol amines over simple amines, giving a fluorescence decrease in response to catechol-containing compounds and a fluorescence increase with other amines (Secor \& Glass, 2004). Coumarin-based fluorescent functional monomers containing a carboxylic acid functionality, $\mathbf{1 1 0}$ and $\mathbf{1 1 1}$ have been synthesized, which allow for the preparation of fluorescent imprinted polymer sensors for chiral amines (Nguyen \& Ansell, 2009). Coumarin aldehyde 66 (Fig. 8) can be utilized as not only a doubly activated Michael acceptor for cyanide but also a highly selective and sensitive fluorescence turn-on probe for proline (G.-J. Kim \& H.-J. Kim, 2010c). Coumarin-azacrown ether conjugate 112 has been developed as a fluorescent probe for identifying melamine (Xiong et al., 2010). Thiocoumarin 113 can be efficiently desulfurized to its corresponding coumarin by the reaction with $\mathrm{mCPBA}$, and results in a pronounced fluorescence turn-on type signaling. The conversion also provides a significant change in absorption behavior which allows a ratiometric analysis, providing a convient detection method for $\mathrm{mCPBA}$ in aqueous environment (Cha et al., 2010). Polymers containing 4,8-dimethylcoumarin have been developed for detection of 2,4-dinitrotoluene (DNT) and 2,4,6-trinitrotoluene (TNT).<smiles>CCCCc1c(C=O)c(=O)oc2cc(N(CC)CC)ccc12</smiles><smiles>CCN(CC)c1ccc2c(CCCCCN(C)Cc3ccccc3[18OH])c(C=O)c(=O)oc2c1</smiles><smiles>C=Cc1ccc2oc(=O)cc(C(=O)O)c2c1</smiles><smiles>Cc1cc(=O)oc2cc(OCCCN3CCN(CCCOc4ccc5c(C)cc(=O)oc5c4)CCN(CCCOc4ccc5c(C)cc(=O)oc5c4)CCN(CCCOc4ccc5c(C)cc(=O)oc5c4)CC3)ccc12</smiles>

111<smiles>CCOc1ccc2ccc(=O)oc2c1</smiles>

113<smiles>CC1(C)C=C(C(=O)Oc2ccc3ccc(=O)oc3c2)C(C)(C)N1[O]</smiles>

112<smiles>CC1(C)CC(C(=O)Oc2ccc3ccc(=O)oc3c2)CC(C)(C)N1[O]</smiles>

Fig. 15. Structures of coumarin-derived fluorescent chemosensors for amines, amino acids or other organic compounds 
The fluorescence quenching of these copolymers in solution can be attributed to the collisional quenching. The response of these polymeric sensors is promising and can easily detect DNT and TNT at few parts per billion levels (Kumar et al., 2010). A novel kind of luminescent vesicular chemosensors for the recognition of biologically important ions and molecules such as imidazoles has been developed by the self-assembly of lipids, amphiphilic binding sites, and fluorescent coumarin reporter dyes that are sensitive to their environment (Gruber et al., 2010). Two hybrid compounds 114 and 115, linked via an ester-bond between the 7-hydroxyl residue of an umbelliferone and a carboxylic acid residue of two nitroxide radicals, act as fluorescence and spin-label probes. The ESR intensities of $\mathbf{1 1 4}$ and $\mathbf{1 1 5}$ are proportionally reduced after the addition of ascorbic acid sodium salt, and their fluorescence intensities are increased maximally by eight- and nine-fold, respectively (Sato et al., 2008).

\subsection{Coumarin-derived fluorescent chemosensors for $\mathrm{TiO}_{2}$, monolayer, polymerization or polymeric micelles}

Structures of coumarin-derived fluorescent chemosensors for detection of $\mathrm{TiO}_{2}$, monolayer, or photopolymerization are shown in Fig. 16. A novel acac-coumarin chromophore linker 116 for robust sensitization of $\mathrm{TiO}_{2}$ has been developed to find molecular chromophores with suitable properties for solar energy conversion. The synthesis and spectroscopic characterization confirms that $\mathbf{1 1 6}$ yields improved sensitization to solar light and provides robust attachment to $\mathrm{TiO}_{2}$ even in aqueous conditions (Xiao et al., 2011). A new amphiphilic coumarin dye, 7-aminocoumarin-4-acetic acid octadecylamide (117) forms a stable monolayer at the air-water interface and may be utilized as an efficient fluorescent probe for monolayer studies (Kele et al., 2001). Performance of amidocoumarins 118-120 as probes for monitoring of cationic photopolymerization of monomers by fluorescence probe technology has been investigated. 7-Diethylamino-4-methylcoumarin 118 can be used for monitoring cationic photopolymerization of monomers using the fluorescence intensity ratio as an indicator of the polymerization process. The replacement of diethylamino group in $\mathbf{1 1 8}$ with benzamido or acetamido groups eliminates the effect of the probe protonation on kinetics of cationic photopolymerization. 7-Benzamido-4-methylcoumarin 119 and 7-acetamido-4methylcoumarin 120 can be used as fluorescent probes for monitoring progress of cationic polymerization of vinyl ethers under stationary measurement conditions, using normalized fluorescence intensity as an indicator of the polymerization progress (Ortyl et al., 2010). Coumarin 153 has been used as a fluorescent probe molecule to monitor the possible micellization of several amphiphilic block copolymers (Basu et al., 2009).<smiles>CC(=O)/C(=C(\C)O)c1cc(=O)oc2ccccc12</smiles>

116<smiles>CCNc1ccc2c(C)cc(=O)oc2c1</smiles>

118<smiles>CCCCCCCCCCCCCCCCCCNC(=O)Cc1cc(=O)oc2cc(N)ccc12</smiles>

117<smiles>Cc1cc(=O)oc2cc(NC(=O)c3ccccc3)ccc12</smiles><smiles>CC(=O)Nc1ccc2c(C)cc(=O)oc2c1</smiles>

Fig. 16. Structures of coumarin-derived fluorescent sensors for detection of $\mathrm{TiO}_{2}$, monolayer, or photopolymerization 


\subsection{Coumarin-derived fluorescent chemosensors for enzymes}

Structures of coumarin-derived fluorescent chemosensors for enzymes are shown in Fig. 17. Hemicyanine-coumarin hybrid $\mathbf{1 2 1}$ represents a new class of far-red emitting fluorogenic dyes whose fluorescence is unveiled through an enzyme-initiated domino reaction and thus acts as a fluorogenic probe for penicillin G acylase (Richard et al., 2008). Similarly novel selfimmolative spacer systems $\mathbf{1 2 2}$ and $\mathbf{1 2 3}$ have been developed and are utilized as fluorogenic probes for sensing penicillin amidase (Meyer et al., 2008). A library of 6-arylcoumarins has been developed as candidate fluorescent sensors of which $\mathbf{1 2 4}$ has the strongest fluorescence intensity, whose quantum yield is similar to that of ethyl 7-diethylaminocoumarin-3carboxylate, a well-known fluorophore as labeling or sensing biomolecule. The transormation of the methoxy group (125) to a hydroxyl group (126) induces a change of fluorescence intensity, which suggests that $\mathbf{1 2 5}$ may be useful as a fluorescent sensor for dealkylating enzymes such as glycosidase. Coumarin 127 shows $50 \%$ decrease of the fluorescence intensity at $\mathrm{pH} 8.0$ compared with that at $\mathrm{pH} 6.0$ and this decrease may be derived from the deprotonation of the triazole ring. Thus $\mathbf{1 2 7}$ may be used as a fluorescent sensor for nitric oxide (Hirano et al., 2007). Histone deacetylases are intimately involved in epigenetic regulation and, thus, are one of the key therapeutic targets for cancer. Coumarinsuberoylanilide hydroxamic acid $\mathbf{1 2 8}$ is a fluorescent probe for determining binding affinities and off-rates of histone deacetylase inhibitors (Singh et al., 2011). A quinonemethide-rearrangement reaction as the off-on optical switch has been successfully implemented into the design of the first long-wavelength latent fluorogenic substrate $\mathbf{1 2 9}$ which is a sensitive fluorimetric indicator for analyte determination in salicylate hydroxylase-coupled dehydrogenase assay (S.-T. Huang et al., 2010). Another switch-on long-wavelength latent fluorogenic substrate $\mathbf{1 3 0}$ is a fluorescent probe for nitroreductase (H.-C. Huang et al., 2011).<smiles></smiles>

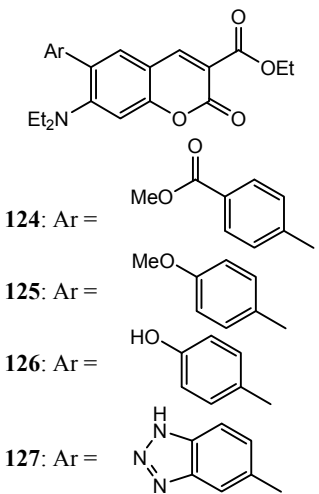<smiles>Cc1cc(=O)oc2cc(NC(=O)CCCCCCC(=O)NO)ccc12</smiles><smiles>N#Cc1c(-c2nc3ccccc3s2)c(=O)oc2cc(OCc3ccc(C(=O)O)c(O)c3)ccc12</smiles>
129

Fig. 17. Structures of coumarin-derived fluorescent chemosensors for enzymes 
Apart from the above-mentioned coumarin-derived fluorescent chemosensors for enzymes, clikable biocompatible nanoparticles have been prepared in a one-pot process by microemulsion polymerization, which are then readily modified by the Huisgen $\mathrm{Cu}(\mathrm{I})$ catalyzed azide-alkyne cycloaddition reaction to afford a coumarin-containing subtilisin responsive nanosensor (Welser et al., 2009). A coumarin-containing time-resolved fluorescence probe for dipeptidyl peptidase 4 has also been reported (Kawaguchi et al., 2010). A coumarin-derived triple-signaling fluorescent probe has been successfully applied for intracellular measurement of different enzyme activity (Y. Li et al., 2011). As shown in Fig. 18, a sensitive, selective, and fluorogenic probe 131 has been developed for monoamine oxidases (MAO A and B). Nonfluorescent aminocoumarin 131 can be converted to fluorescent pyrrolocoumarin 132 in the presence of MAO A and B (G. Chen et al., 2005). A new fluorogenic transformation based on a quinone reduction/lactonization sequence as shown in Fig. 19 has been developed and evaluated as a tool for probing redox phenomena in a biochemical context.

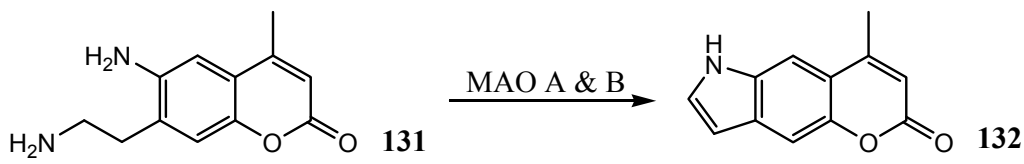

Fig. 18. Systematic mapping of aminocoumarin $\mathbf{1 3 1}$ and the corresponding pyrrolocoumarin 132

\subsection{Coumarin-derived fluorescent chemosensors for proteins, DNA, RNA and other uses}

Structures of coumarin-derived fluorescent chemosensors for DNA, RNA, nitroxyl and proteins are shown in Fig. 20. A novel coumarin C-riboside $\mathbf{1 3 3}$ is designed and synthesized based on the well-known photoprobe Coumarin 102. The coumarin C-glycoside $\mathbf{1 3 3}$ has been incorporated synthetically into DNA oligomers, and has been used to probe ultrafast dynamics of duplex DNA using time-resolved Stokes shift methods (Coleman et al., 2007). Coumarin-triazole 134 reacts with $\mathrm{CuCl}_{2}$ to form a chelated $\mathrm{Cu}(\mathrm{II})-\mathbf{1 3 4}$ complex which shows highly selective turn-on type fluorogenic behavior upon addition of Angeli's salt $\left(\mathrm{Na}_{2} \mathrm{~N}_{2} \mathrm{O}_{3}\right)$ and can be used for detection of nitroxyl in living cells (Zhou et al., 2011). A simple coumarin derivative 7-diethylaminocoumarin-3- carboxylic acid $\mathbf{1 3 5}$ has been used as an acceptor to construct a useful and effective FRET system for detection of RNA-small molecule binding (Xie et al., 2009). Coumarin dye bearing an indolenine substituent 136 displays high emission and bright fluorescence and offers promise as an fluorescent chemosensor for protein detection (Kovalska et al., 2010). Coumarin-containing trifunctional probe 137, assembled using a cleavable linker, is useful for efficient enrichment and detection of glycoproteins (Tsai et al., 2010). Coumarin 6 has been used as a fluorescent probe to monitor protein aggregation and can distinguish between both amorphors and fibrillar aggregates (Makwana et al., 2011). An $\mathrm{S}_{N} \mathrm{Ar}$ reaction-triggered fluorescence probe is developed using a new fluorogenic compound derivatized from 7-aminocoumarin for oligonucleotides detection (Shibata et al., 2009). Coumarin C343 has been conjugated to silica nanoparticles and entrapped in a sol-gel matrix to produce a nanosensor capable of monitoring lipid peroxidation (Baker et al., 2007). Coumarin-containing dual-emission chemosensors for nucleoside polyphosphates have been developed based on a new 
mechanism involving binding-induced recovery of FRET. These sensors demonstrate that binding-induced modulation of spectral overlap is a powerful strategy for the rational design of FRET-based chemosensors (Kurishita et al., 2010).<smiles></smiles><smiles>CCNc1ccc2cc(-n3cc(CN(Cc4ccccn4)Cc4ccccn4)nn3)c(=O)oc2c1</smiles><smiles>CN1/C(=C\C=C\C(=O)c2c(O)c3ccccc3oc2=O)C(C)(C)c2ccccc21</smiles><smiles>CCNc1ccc2cc(C(=O)O)c(=O)oc2c1</smiles><smiles>CCCCCC1SCC2NC(=O)NC21</smiles><smiles>CN(CC(=O)NCCSSCCNC=O)c1ccc2cc(N)c(=O)oc2c1</smiles>

Fig. 19. Structures of coumarin-derived fluorescent chemosensors for DNA, RNA, nitroxyl and proteins

\section{Conclusions}

Coumarin-derived fluorescent chemosensors have been extensively applied in a variety of fields. Though these sensors are effective for detection of many species, their performance toward different species might decrease in the following order: metal ions, anions, biothiols, enzymes, $\mathrm{pH}$, amines and amino acids, chemical warfare agents, proteins, hydrogen peroxide, hydroxyl radicals, polymerization and polymeric micelles, DNA and RNA, oxygen, titania. Continuous efforts will be devoted to development of fluorescent chemosensors with higher selectivity and sensitivity for more single target or simultaneously for multiple targets, thus providing practical fluorescent chemosensors for application in environmental chemistry, analytical chemistry, and bio-medicinal science.

\section{References}

Abbas, M. E.; Luo, W.; Zhu, L.; Zou, J. \& Tang, H. (2010). Fluorometric determination of hydrogen peroxide in milk by using a Fenton reaction system. Food Chem., vol.120, No.1, (May 2010), pp. 327-331, ISSN 0308-8146

Ast, S.; Müller, H.; Flehr, R.; Klamroth, T.; Walz, B. \& Holdt, H.-J. (2011). High $\mathrm{Na}^{+}$and $\mathrm{K}^{+}-$ induced fluorescence enhancement of a $\Pi$-conjugated phenylaza-18-crown-6triazol-substituted coumarin fluoroionophore. Chem. Commun., vol.47, No.16, (April 2011), pp. 4685-4687, ISSN 1359-7345

Baker, N.; Greenway, G. M.; Wheatley, R. A. \& Wiles, C. (2007). A chemiluminescence nanosensor to monitor lipid peroxidation. Analyst, vol.132, No.2, (January 2007), pp. 104-106, ISSN 0003-2654

Bangar Raju, B. \& Varadarajan, T. S. (1995). Spectroscopic studies of 7-diethylamino-3styrylcoumarins. J. Photochem. Photobio. A, vol.85, No.3, (January 1995), pp. 263-267, ISSN 1010-6030 
Basu, S.; Chatterjee, D. P.; Chatterjee, U.; Mondal, S. \& Mandal, D. (2009). Fluorescence probing of block copolymeric micelles using Coumarin 153. Colloids Surf. A, vol.341, No.1-3, (June 2009), pp. 13-20, ISSN 0927-7757

Capitán-Vallvey, L. F.; Fernández-Ramos, M. D.; Lapresta-Fernández, A.; Brunet, E.; Rodríguez-Ubis, J. C. \& Juanes, O. (2006). Magnesium optical one-shot sensor based on a coumarin chromoionophore. Talanta, vol.68, No.5, (February 2006), pp. 16631670, ISSN 0039-9140

Cha, S.; Hwang, J.; Choi, M. G. \& Chang, S.-K. (2010). Dual signaling of $m$-chloroperbenzoic acid by desulfurization of thiocoumarin. Tetrahedron Lett., vol.51, No.50, (December 2010), pp. 6663-6665, ISSN 0040-4039

Chandrasekhar, V.; Bag, P. \& Pandey, M. D. (2009). Phosphorus-supported multidentate coumarin-containing fluorescence sensors for $\mathrm{Cu}^{2+}$. Tetrahedron, vol.65, No.47, (November 2009), pp. 9876-9883, ISSN 0040-4020

Chattopadhyay, N.; Mallick, A. \& Sengupta, S. (2006). Photophysical studies of 7-hydroxy-4methyl-8-(4'-methylpiperazin-1'-yl) methylcoumarin: a new fluorescent chemosensor for zinc and nickel ions in water. J. Photochem. Photobio. A, vol.177, No.1, (January 2006), pp. 55-60, ISSN 1010-6030

Chen, C.-T. \& Huang, W.-P. (2002). A highly selective fluorescent chemosensor for lead ions. J. Am. Chem. Soc., vol.124, No.22, (June 2002), pp. 6246-6247, ISSN 0002-7863

Chen, G.; Yee, D. J.; Gubernator, N. G. \& Sames, D. (2005). Design of optical switches as metabolic indicators: new fluorogenic probes for monoamine oxidases (MAO A and B). J. Am. Chem. Soc., vol.127, No.13, (April 2005), pp. 4544-4545, ISSN 00027863

Chen, K.; Guo, Y.; Lu, Z.; Yang, B. \& Shi, Z. (2010). Novel coumarin-based fluorescent probe for selective detection of bisulfite anion in water. Chin. J. Chem., vol.28, No.1, (January 2010), pp. 55-60, ISSN 1001-604X

Chen, X.; Xi, H.; Sun, X.; Zhao, T.; Meng, Q. \& Jiang, Y. (2011). Synthesis and fluorescent probes properties of a coumarin-based piperazine containing fluorine. Chin. J. Org. Chem., vol.31, No.4, (April 2011), pp. 544-547, ISSN 0253-2786

Cho, Y.-S. \& Ahn, K. H. (2010). A 'turn-on' fluorescent probe that selectively responds to inorganic mercury species. Tetrahedron Lett., vol.51, No.29, (July 2010), pp. 38523854, ISSN 0040-4039

Choi, K. \& Hamilton, A. D. (2001). A dual channel fluorescence chemosensor for anions involving intermolecular excited state proton transfer. Angew. Chem. Int. Ed., vol.40, No.20, (October 2001), pp. 3912-3915, ISSN 1433-7851

Choi, M. G.; Kim, Y. H.; Namgoong, J. E. \& Chang, S.-K. (2009). Hg2+-selective chromogenic and fluorogenic chemodosimeter based on thiocoumarins. Chem. Commun., No.24, (June 2009), pp. 3560-3562, ISSN 1359-7345

Ciesienski, K. L.; Hyman, L. M.; Derisavifard, S. \& Franz, K. J. (2010). Toward the detection of cellular copper(II) by a light-activated fluorescence increase. Inorg. Chem., vol.49, No.15, (August 2010), pp. 6808-6810, ISSN 0020-1669

Coleman, R. S.; Berg, M. A. \& Murphy, C. J. (2007). Coumarin base-pair replacement as a fluorescent probe of ultrafast DNA dynamics. Tetrahedron, vol.63, No.17, (April 2007), pp. 3450-3456, ISSN 0040-4020

Dale, T. J. \& Rebek, J., Jr. (2009). Hydroxy oximes as organophosphorus nerve agent sensors. Angew. Chem. Int. Ed., vol.48, No.42, (October 2009), pp. 7850-7852, ISSN 1433-7851

Das, P.; Ghosh, A.; Kesharwani, M. K.; Ramu, V.; Ganguly, B. \& Das, A. (2011). ZnII$2,2^{\prime}: 6^{\prime}, 2^{\prime \prime}$-Terpyridine-based complex as fluorescent chemosensor for PPi, AMP and ADP. Eur. J. Inorg. Chem., No.20, (July 2011), pp. 3050-3058, ISSN 1434-1948 
Dong, Y.; Li, J.; Jiang, X.; Song, F.; Cheng, Y. \& Zhu, C. (2011). $\mathrm{Na}^{+}$triggered fluorescence sensors for $\mathrm{Mg}^{2+}$ detection based on a coumarin salen moiety. Org. Lett., vol.13, No.9, (May 2011), pp. 2252-2255, ISSN 1523-7060

Du, L.; Li, M.; Zheng, S. \& Wang, B. (2008). Rational design of a fluorescent hydrogen peroxide probe based on the umbelliferone fluorophore. Tetrahedron Lett., vol.49, No.19, (May 2008), pp. 3045-3048, ISSN 0040-4039

Du Ý, L.; Ni Ý, N.; Li, M. \& Wang, B. (2010). A fluorescent hydrogen peroxide probe based on a 'click' modified coumarin fluorophore. Tetrahedron Lett., vol.51, No.8, (February 2010), pp. 1152-1154, ISSN 0040-4039

Feuster, E. K. \& Glass, T. E. (2003). Detection of amines and unprotected amino acids in aqueous conditions by formation of highly fluorescent iminium ions. J. Am. Chem. Soc., vol.125, No.52, (December 2003), pp. 16174-16175, ISSN 0002-7863

Galardon, E.; Tomas, A.; Roussel, P. \& Artaud, I. (2009). New fluorescent zinc complexes: towards specific sensors for hydrogen sulfide in solution. Dalton Trans., No.42, (November 2009), pp. 9126-9130, ISSN 1477-9226

Ganea, G. M.; Kolic, P. E.; El-Zahab, B. \& Warner, I. M. (2011). Ratiometric coumarin-neutral red (CONER) nanoprobe for detection of hydroxyl radicals. Anal. Chem., vol.83, No.7, (April 2011), pp. 2576-2581, ISSN 0003-2700

González-Béjar, M.; Frenette, M.; Jorge, L. \& Scaiano, J. C. (2009). 7-Mercapto-4methylcoumarin as a reporter of thiol binding to the CdSe quantum dot surface. Chem. Commun., No.22, (June 2009), pp. 3202-3204, ISSN 1359-7345

Gruber, B.; Stadlbauer, S.; Späth, A.; Weiss, S.; Kalinina, M. \& König, B. (2010). Modular chemosensors from self-assembled vesicle membranes with amphiphilic binding sites and reporter dyes. Angew. Chem. Int. Ed., vol.49, No.39, (September 2010), pp. 7125-7128, ISSN 1433-7851

He, G.; Zhang, X.; He, C.; Zhao, X. \& Duan, C. (2010b). Ratiometric fluorescence chemosensors for copper(II) and mercury(II) based on FRET systems. Tetrahedron, vol.66, No.51, (December 2010), pp. 9762-9768, ISSN 0040-4020

He, G.; Zhao, X.; Zhang, X.; Fan, H.; Wu, S.; Li, H.; He, C. \& Duan, C. (2010a). A turn-on PET fluorescence sensor for imaging $\mathrm{Cu}^{2+}$ in living cells. New J. Chem., vol.34, No.6, (June 2010), pp. 1055-1058, ISSN 1144-0546

He, X.-P.; Song, Z.; Wang, Z.-Z.; Shi, X.-X. \& Chen, K. (2011). Creation of 3,4-bistriazolocoumarin-sugar conjugates via fluorogenic dual click chemistry and their quenching specificity with silver(I) in aqueous media. Tetrahedron, vol.67, No.19, (May 2011), pp. 3343-3347, ISSN 0040-4020

Helal, A.; Rashid, M. H. O.; Choi, C.-H. \& Kim, H.-S. (2011). Chromogenic and fluorogenic sensing of $\mathrm{Cu}^{2+}$ based on coumarin. Tetrahedron, vol.67, No.15, (April 2011), pp. 2794-2802, ISSN 0040-4020

Hirano, T.; Hiromoto, K. \& Kagechika, H. (2007). Development of a library of 6arylcoumarins as candidate fluorescent sensors. Org. Lett., vol.9, No.7, (March 2007), pp. 1315-1318, ISSN 1523-7060

Hong, S. W. \& Jo, W. H. (2008). A fluorescence resonance energy transfer probe for sensing pH in aqueous solution. Polymer, vol.49, No. 19, (September 2008), pp. 4180-4187, ISSN 0032-3861

Hu, X.; Zhang, X.; He, G.; He, C. \& Duan, C. (2011). A FRET approach for luminescence sensing $\mathrm{Cr}^{3+}$ in aqueous solution and living cells through functionalizing glutathione and glucose moieties. Tetrahedron, vol.67, No.6, (February 2011), pp. 1091-1095, ISSN 0040-4020 
Huang, H.-C.; Wang, K.-L.; Huang, S.-T.; Lin, H.-Y. \& Lin, C.-M. (2011). Development of a sensitive long-wavelength fluorogenic probe for nitroreductase: a new fluorimetric indicator for analyte determination by dehydrogenase-coupled biosensors. Biosensors Bioelectronics, vol.26, No.8, (April 2011), pp. 3511-3516, ISSN 0956-5663

Huang, S.; He, S.; Lu, Y.; Wei, F.; Zeng, X. \& Zhao, L. (2011). Highly sensitive and selective fluorescent chemosensor for $\mathrm{Ag}^{+}$based on a coumarin- $\mathrm{Se}_{2} \mathrm{~N}$ chelating conjugate. Chem. Commun., vol.47, No.8, (February 2011), pp. 2408-2410, ISSN 1359-7345

Huang, S.-T.; Teng, C.-J.; Lee, Y.-H.; Wu, J.-Y.; Wang, K.-L. \& Lin, C.-M. (2010). Design and synthesis of a long-wavelength latent fluorogenic substrate for salicylate hydroxylase: a useful fluorimetric indicator for analyte determination by dehydrogenase- coupled biosensors. Anal. Chem., vol.82, No.17, (September 2010), pp. 7329-7334, ISSN 0003-2700

Jang, Y. J.; Moon, B.-S.; Park, M. S.; Kang, B.-G.; Kwon, J. Y.; Hong J. S. J.; Yoon, Y. J.; Lee, K. D. \& Yoon, J. (2006). New cavitand derivatives bearing four coumarin groups as fluorescent chemosensors for $\mathrm{Cu}^{2+}$ and recognition of dicarboxylates utilizing $\mathrm{Cu}^{2+}$ complex. Tetrahedron Lett., vol.47, No.16, (April 2006), pp. 2707-2710, ISSN 00404039

Jiang, W. \& Wang, W. (2009). A selective and sensitive "turn-on" fluorescent chemodosimeter for $\mathrm{Hg}^{2+}$ in aqueous media via $\mathrm{Hg}^{2+}$ promoted facile desulfurization-lactonization reaction. Chem. Commun., No.26, (July 2009), pp. 39133915, ISSN 1359-7345

Jung, H. S.; Han, J. H.; Habata, Y.; Kang, C. \& Kim, J. S. (2011b). An iminocoumarin-Cu(II) ensemble-based chemodosimeter toward thiols. Chem. Commun., vol.47, No.18, (May 2011), pp. 5142-5144, ISSN 1359-7345

Jung, H. S.; Ko, K. C.; Kim, G.-H.; Lee, A.-R.; Na, Y.-C.; Kang, C.; Lee, J. Y. \& Kim, J. S. (2011a). Coumarin-based thiol chemosensor: synthesis, turn-on mechanism, and its biological application. Org. Lett., vol.13, No.6, (March 2011), pp. 1498-1501, ISSN 1523-7060

Jung, H. S.; Ko, K. C.; Lee, J. H.; Kim, S. H.; Bhuniya, S.; Lee, J. Y.; Kim, Y.; Kim, S. J. \& Kim, J. S. (2010). Rationally designed fluorescence trun-on sensors: a new design strategy based on orbital control. Inorg. Chem., vol.49, No.18, (September 2010), pp. 85528557, ISSN 0020-1669

Jung, H. S.; Kwon, P. S.; Lee, J. W.; Kim, J. I.; Hong, C. S.; Kim, J. W.; Yan, S.; Lee, J. Y.; Lee, J. H.; Joo, T. \& Kim, J. S. (2009). Coumarin-derived $\mathrm{Cu}^{2+}$-selective fluorescence sensor: synthesis, mechanisms, and applications in living cells. J. Am. Chem. Soc., vol.131, No.5, (February 2009), pp. 2008-2012, ISSN 0002-7863

Kawaguchi, M.; Okabe, T.; Terai, T.; Hanaoka, K.; Kojima, H.; Minegishi, I. \& Nagano, T. (2010). A time-resolved fluorescence probe for dipeptidyl peptidase 4 and its application in inhibitor screening. Chem. Eur. J., vol.16, No.45, (December 2010), pp. 13479-13486, ISSN 0947-6539

Kele, P.; Orbulescu, J.; Mello, S. V.; Mabrouki, M. \& Leblanc, R. M. (2001). LangmuirBlodgett film characterization of a new amphiphilic coumarin derivative. Langmuir, vol.17, No.23, (November 2001), pp. 7286-7290, ISSN 0743-7463.

Kim, G.-J. \& Kim, H.-J. (2010a). Doubly activated coumarin as a colorimetric and fluorescent chemodosimeter for cyanide. Tetrahedron Lett., vol.51, No.1, (January 2010), pp. 185187, ISSN 0040-4039

Kim, G.-J. \& Kim, H.-J. (2010b). Coumarinyl aldehyde as a Michael acceptor type of colorimetric and fluorescent probe for cyanide in water. Tetrahedron Lett., vol.51, No.21, (May 2010), pp. 2914-2916, ISSN 0040-4039 
Kim, G.-J. \& Kim, H.-J. (2010c). Highly selective and sensitive fluorescence turn-on probe for proline. Tetrahedron Lett., vol.51, No.35, (September 2010), pp. 4670-4672, ISSN 00404039

Kim, G.-J.; Lee, K.; Kwon, H. \& Kim, H.-J. (2011). Ratiometric fluorescence imaging of cellular glutathione. Org. Lett., vol.13, No.11, (June 2011), pp. 2799-2801, ISSN 15237060

Kim, H. J.; Bhuniya, S.; Mahajan, R. K.; Puri, R.; Liu, H.; Ko, K. C.; Lee, J. Y. \& Kim, J. S. (2009b). Fluorescence turn-on sensors for $\mathrm{HSO}_{4}^{-}$. Chem. Commun., No.46, (December 2009), pp. 7128-7130, ISSN 1359-7345

Kim, H. J.; Kim, Y.; Kim, S. J.; Park, S. Y.; Lee, S. Y.; Kim, J. H.; No, K. \& Kim, J. S. (2010). Iminocoumarin-based $\mathrm{Hg}(\mathrm{II})$ ion probe. Bull. Korean Chem. Soc., vol.31, No.1, (January 2010), pp. 230-233, ISSN 0253-2964

Kim, H. J.; Ko, K. C.; Lee, J. H.; Lee, J. Y. \& Kim, J. S. (2011). KCN sensor: unique chromogenic and 'turn-on' fluorescent chemodosimeter: rapid response and high selectivity. Chem. Commun., vol.47, No.10, (March 2011), pp. 2886-2888, ISSN 13597345

Kim, H. J.; Park, J. E.; Choi, M. G.; Ahn, S. \& Chang, S.-K. (2009a). Selective chromogenic and fluorogenic signalling of $\mathrm{Hg}^{2+}$ ions using a fluorescein-coumarin conjugate. Dyes Pigments, vol.84, No.1, (January 2010), pp. 54-58, ISSN 0143-7208

Kim, H. M.; Yang, P. R.; Seo, M. S.; Yi, J.-S.; Hong, J. H.; Jeon, S.-J.; Ko, Y.-G.; Lee, K. J. \& Cho, B. R. (2007). Magnesium ion selective two-photon fluorescent probe based on a benzo[h]chromene derivative for in vivo imaging. J. Org. Chem., vol.72, No.6, (March 2007), pp. 2088-2096, ISSN 0022-3263

Kim, J. H.; Kim, H. J.; Kim, S. H.; Lee, J. H.; Do, J. H.; Kim, H.-J.; Lee, J. H. \& Kim, J. S. (2009). Fluorescent coumarinyldithiane as a selective chemodosimeter for mercury(II) ion in aqueous solution. Tetrahedron Lett., vol.50, No.43, (October 2009), pp. 5958-5961, ISSN 0040-4039

Kim, M. H.; Jang, H. H.; Yi, S.; Chang, S.-K. \& Han, M. S. (2009). Coumarin-derivative-based off-on catalytic chemodosimeter for $\mathrm{Cu}^{2+}$ ions. Chem. Commun., No.32, (August 2009), pp. 4838-4840, ISSN 1359-7345

Kim, S. K.; Lee, D. H.; Hong, J.-I. \& Yoon, J. (2009). Chemosensors for pyrophosphate. Acc. Chem. Res., vol.42, No.1, (January 2009), pp. 23-31, ISSN 0001-4842

Kim, S. Y.; Park, J.; Koh, M.; Park, S. B. \& Hong, J.-I. (2009). Fluorescent probe for detection of fluoride in water and bioimaging in A549 human lung carcinoma cells. Chem. Commun., No.31, (August 2009), pp. 4735-4737, ISSN 1359-7345

Ko, K. C.; Wu, J.-S.; Kim, H. J.; Kwon, P. S.; Kim, J. W.; Bartsch, R. A.; Lee, J. Y. \& Kim, J. S. (2011). Rationally designed fluorescence 'turn-on' sensor for $\mathrm{Cu}^{2+}$. Chem. Commun., vol.47, No.11, (March 2011), pp. 3165-3167, ISSN 1359-7345

Kovalska, V. B.; Volkova, K. D.; Manaev, A. V.; Losytskyy, M. Y.; Okhrimenko, I. N.; Traven, V. F. \& Yarmoluk, S. M. (2010). 2-Quinolone and coumarin polymethines for the detection of proteins using fluorescence. Dyes Pigments, vol.84, No.2, (February 2010), pp. 159-164, ISSN 0143-7208

Kulatilleke, C. P.; de Silva, S. A. \& Eliav, Y. (2006). A coumarin based fluorescent photoinduced electron transfer cation sensor. Polyhedron, vol.25, No.13, (September 2006), pp. 2593-2596, ISSN 0277-5387

Kumar, A.; Pandey, M. K.; Anandakathir, R.; Mosurkal, R.; Parmar, V. S.; Watterson, A. C. \& Kumar, J. (2010). Sensory response of pegylated and siloxanated 4,8dimethylcoumarins: a fluorescence quenching study by nitro aromatics. Sensors Actuators B, vol.147, No.1, (May 2010), pp. 105-110, ISSN 0925-4005 
Kurishita, Y.; Kohira, T.; Ojida, A. \& Hamachi, I. (2010). Rational design of FRET-based ratiometric chemosensors for in vitro and in cell fluorescence analyses of nucleoside polyphosphates. J. Am. Chem. Soc., vol.132, No.38, (September 2010), pp. 13290-13299, ISSN 0002-7863

Kwon, H.; Lee, K. \& Kim, H.-J. (2011). Coumarin-malonitrile conjugate as a fluorescent turnon probe for biothiols and its cellular expression. Chem. Commun., vol.47, No.6, (February 2011), pp. 1773-1775, ISSN 1359-7345

Lau, Y. H.; Price, J. R.; Todd, M. H. \& Rutledge, P. J. (2011). A click fluorophore sensor that can distinguish $\mathrm{Cu}^{\mathrm{II}}$ and $\mathrm{HgII}^{\mathrm{II}}$ via selective anion-induced demetallation. Chem. Eur. J., vol.17, No.10, (March 2011), pp. 2850-2858, ISSN 0947-6539

Lee, D.-N.; Kim, G.-J. \& Kim, H.-J. (2009). A fluorescent coumarinylalkyne probe for the selective detection of mercury(II) ion in water. Tetrahedron Lett., vol.50, No.33, (August 2009), pp. 4766-4768, ISSN 0040-4039

Lee, J. H.; Jeong, A. R.; Shin, I.-S.; Kim, H.-J. \& Hong, J.-I. (2010). Fluorescence turn-on sensor for cyanide based on a cobalt(II)-coumarinylsalen complex. Org. Lett., vol.12, No.4, (February 2010), pp. 764-767, ISSN 1523-7060

Lee, K.-S.; Kim, H.-J.; Kim, G.-H.; Shin, I. \& Hong, J.-I. (2008a). Fluorescent chemodosimeter for selective detection of cyanide in water. Org. Lett., vol.10, No.1, (January 2008), pp. 49-51, ISSN 1523-7060

Lee, K.-S.; Kim, T.-K.; Lee, J. H.; Kim, H.-J. \& Hong, J.-I. (2008b). Fluorescence turn-on probe for homocysteine and cysteine in water. Chem. Commun., No.46, (December 2008), pp. 6173-6175, ISSN 1359-7345

Lee, M.; Gubernator, N. G.; Sulzer, D. \& Sames, D. (2010). Development of pH-responsive fluorescent false neurotransmitters. J. Am. Chem. Soc., vol.132, No.26, (July 2010), pp. 8828-8830, ISSN 0002-7863

Lee, S. H.; Helal, A. \& Kim, H.-S. (2010). Fluorescence sensing properties of thiazolobenzocrown ether incorporating coumarin. Bull. Korean Chem. Soc., vol.31, No.3, (March 2010), pp. 615-619, ISSN 0253-2964

Li, H.; Cai, L.; Li, J.; Hu, Y.; Zhou, P. \& Zhang, J. (2011). Novel coumarin fluorescent dyes: synthesis, structural characterization and recognition behavior towards $\mathrm{Cu}(\mathrm{II})$ and Ni(II). Dyes Pigments, vol.91, No.3, (December 2011), pp. 309-316, ISSN 0143-7208

Li, H.; Gao, S. \& Xi, Z. (2009). A colorimetric and "turn-on" fluorescent chemosensor for $\mathrm{Zn}$ (II) based on coumarin Schiff-base derivative. Inorg. Chem. Commun., vol.12, No.4, (April 2009), pp. 300-303, ISSN 1387-7003

Li, J.; Lin, H.; Cai, Z. \& Lin, H. (2009). A novel coumarin-based switching-on fluorescent and colorimetric sensor for F-. J. Lumin., vol.129, No.5, (May 2009), pp. 501-505, ISSN 0022-2313

Li, N.; Xiang, Y. \& Tong, A. (2010). Highly sensitive and selective "turn-on" fluorescent chemodosimeter for $\mathrm{Cu}^{2+}$ in water via $\mathrm{Cu}^{2+}$-promoted hydrolysis of lactone moiety in coumarin. Chem. Commun., vol.46, No.19, (May 2010), pp. 3363-3365, ISSN 13597345

Li, Y.; Wang, H.; Li, J.; Zheng, J.; Xu, X. \& Yang, R. (2011). Simultaneous intracellular $\beta$-Dglucosidase and phosphodiesterase I activities measurements based on a triplesignaling fluorescent probe. Anal. Chem., vol.83, No.4, (February 2011), pp. 12681274, ISSN 0003-2700

Lim, N. C. \& Brückner, C. (2004). DPA-substituted coumarins as chemosensors for zinc(II): modulation of the chemosensory characteristics by variation of the position of the chelate on the coumarin. Chem. Commun., No.9, (May 2004), pp. 1094-1095, ISSN 1359-7345 
Lim, N. C.; Pavlova, S. V. \& Brückner, C. (2009). Squaramide hydroxamate-based chemidosimeter responding to iron(III) with a fluorescence intensity increase. Inorg. Chem., vol.48, No.3, (February 2009), pp. 1173-1182, ISSN 0020-1669

Lim, N. C.; Schuster, J. V.; Porto, M. C.; Tanudra, M. A.; Yao, L.; Freake, H. C. \& Brückner, C. (2005). Coumarin-based chemosensors for zinc(II): toward the determination of the design algorithm for CHEF-type and ratiometric probes. Inorg. Chem., vol.44, No.6, (March 2005), pp. 2018-2030, ISSN 0020-1669

Lim, S.-Y.; Lee, S.; Park, S. B. \& Kim, H.-J. (2011). Highly selective fluorescence turn-on probe for glutathione. Tetrahedron Lett., vol.52, No.30, (July 2011), pp. 3902-3904, ISSN 0040-4039

Lin, W.; Cao, X.; Yuan, L. \& Ding, Y. (2010b). Double functional group transformations for fluorescent probe construction: a fluorescence turn-on probe for thioureas. Chem. Eur. J., vol.16, No.22, (June 2010), pp. 6454-6457, ISSN 0947-6539

Lin, W.; Long, L. Tan, W. (2010a). A highly sensitive fluorescent probe for detection of benzenethiols in environmental samples and living cells. Chem. Commun., vol.46, No.9, (March 2010), pp. 1503-1505, ISSN 1359-7345

Lin, W.; Yuan, L.; Cao, X.; Tan, W. \& Feng, Y. (2008). A coumarin-based chromogenic sensor for transition-metal ions showing ion-dependent bathochromic shift. Eur. J. Org. Chem., No.29, (October 2008), pp. 4981-4987, ISSN 1434-193X

Lin, W.; Yuan, L.; Cao, Z.; Feng, J. \& Feng, Y. (2009). Fluorescence enhancement of coumarin-quinoline by transition metal ions: detection of paramagnetic $\mathrm{Ni}^{2+}$ and $\mathrm{Co}^{2+}$. Dyes Pigments, vol.83, No.1, (October 2009), pp. 14-20, ISSN 0143-7208

Ma, Q.-J.; Zhang, X.-B.; Zhao, X.-H.; Jin, Z.; Mao, G.-J.; Shen, G.-L. \& Yu, R.-Q. (2010). A highly selective fluorescent probe for $\mathrm{Hg}^{2+}$ based on a rhodamine-coumarin conjugate. Anal. Chim. Acta, vol.663, No.1, (March 2010), pp. 85-90, ISSN 0003-2670

Ma, W.; Xu, Q.; Du, J.; Song, B.; Peng, X.; Wang, Z.; Li, G. \& Wang, X. (2010). A Hg2+selective chemodosimeter based on desulfurization of coumarin thiosemicarbazide in aqueous media. Spectrochim. Acta A, vol.76, No.2, (July 2010), pp. 248-252, ISSN 1386-1425

Ma, Y. M. \& Hider, R. C. (2009). The selective quantification of iron by hexadentate fluorescent probes. Bioorg. Med. Chem., vol.17, No.23, (December 2009), pp. 80938101, ISSN 0960-894X

Mahapatra, A. K.; Hazra, G.; Roy, J. \& Sahoo, P. (2011). A simple coumarin-based colorimetric and ratiometric chemosensor for acetate and a selective fluorescence turn-on probe for iodide. J. Lumin., vol.131, No.7, (July 2011), pp. 1255-1259, ISSN 0022-2313

Maity, D. \& Govindaraju, T. (2010). Conformationally constrained (cumarin-triazolylbipyridyl) click fluoroionophore as a selective $\mathrm{Al}^{3+}$ sensor. Inorg. Chem., vol.49, No.16, (August 2010), pp. 7229-7231, ISSN 0020-1669

Makwana, P. K.; Jethva, P. N. \& Roy, I. (2011). Coumarin 6 and 1,6-diphenyl-1,3,5-hexatriene (DPH) as fluorescent probes to monitor protein aggregation. Analyst, vol.136, No.10, (May 2011), pp. 2161-2167, ISSN 0003-2654

Meyer, Y.; Richard, J.-A.; Massonneau, M.; Renard, P.-Y. \& Romieu, A. (2008). Development of a new nonpeptidic self-immolative spacer. Application to the design of protease sensing fluorogenic probes. Org. Lett., vol.10, No.8, (April 2008), pp. 1517-1520, ISSN 1523-7060

Miyaji, H.; Kim, H.-K.; Sim, E.-K.; Lee, C.-K.; Cho, W.-S.; Sessler, J. L. \& Lee, C.-H. (2005). Coumarin-strapped calyx[4]pyrrole: a fluorogenic anion receptor modulated by 
cation and anion binding. J. Am. Chem. Soc., vol.127, No.36, (September 2005), pp. 12510-12512, ISSN 0002-7863

Mizukami, S.; Nagano, T.; Urano, Y.; Odani, A. \& Kikuchi, K. (2002). A fluorescent anion sensor that works in neutral aqueous solution for bioanalytical application. J. Am. Chem. Soc., vol.124, No.15, (April 2002), pp. 3920-3925, ISSN 0002-7863

Mizukami, S.; Okada, S.; Kimura, S. \& Kikuchi, K. (2009). Design and synthesis of coumarinbased $\mathrm{Zn}^{2+}$ probes for ratiometric fluorescence imaging. Inorg. Chem., vol.48, No.16, (August 2009), pp. 7630-7638, ISSN 0020-1669

Namba, K.; Kobayashi, K.; Murata, Y.; Hirakawa, H.; Yamagaki, T.; Iwashita, T.; Nishizawa, M.; Kusumoto, S. \& Tanino, K. (2010). Mugineic acid derivatives as molecular probes for the mechanistic elucidation of iron acquisition in barley. Angew. Chem. Int. Ed., vol.49, No.51, (December 2010), pp. 9956-9959, ISSN 1433-7851

Nguyen, T. H. \& Ansell, R. J. (2009). Fluorescent imprinted polymer sensors for chiral amines. Org. Biomol. Chem., vol.7, No.6, (March 2009), pp. 1211-1220, ISSN 14770520

Ortyl, J.; Sawicz, K. \& Popielarz, R. (2010). Performance of amidocoumarins as probes for monitoring of cationic photopolymerization of monomers by fluorescence probe technology. J. Polym. Sci. A, vol.48, No.20, (October 2010), pp. 4522-4528, ISSN 10990518

Pagona, G.; Economopoulos, S. P.; Tsikalas, G. K.; Katerionpoulos, H. E. \& Tagmatarchis, N. (2010). Fullerene-coumarin dyad as a selective metal receptor: synthesis, photophysical properties, electrochemistry and ion binding studies. Chem. Eur. J., vol.16, No.39, (October 2010), pp. 11969-11976, ISSN 0947-6539

Pan, J.; Downing, J. A.; McHale, J. L. \& Xian, M. (2009). A fluorogenic dye activated by Snitrosothiols. Mol. BioSyst., vol.5, No.9, (September 2009), pp. 918-920, ISSN 1742$206 X$

Ray, D.; Nag, A.; Jana, A.; Goswami, D. \& Bharadwaj, P. K. (2010). Coumarin derived chromophores in the donor-acceptor-donor format that give fluorescence enhancement and large two-photon activity in presence of specific metal ions. Inorg. Chim. Acta, vol.363, No.12, (October 2010), pp. 2824-2832, ISSN 0020-1693

Richard, J.-A.; Massonneau, M.; Renard, P.-Y. \& Romieu, A. (2008). 7-Hydroxycoumarinhemicyanine hybrids: a new class of far-red emitting fluorogenic dyes. Org. Lett., vol.10, No.19, (October 2008), pp. 4175-4178, ISSN 1523-7060

Roussakis, E.; Pergantis, S. A. \& Katerinopoulos, H. E. (2008). Coumarin-based ratiometric fluorescent indicators with high specificity for lead ions. Chem. Commun., No.46, (December 2008), pp. 6221-6223, ISSN 1359-7345

Royo, S.; Martínez-Máñez, R.; Sancenón, F.; Costero, A. M.; Parra, M. \& Gil, S. (2007). Chromogenic and fluorogenic reagents for chemical warfare nerve agents' detection. Chem. Commun., No.46, (JDecember 2007), pp. 4839-4847, ISSN 1359-7345

Ryu, D. H.; Noh, J. H. \& Chang, S.-K. (2010). Selective ratiometric signaling of $\mathrm{Hg}^{2+}$ ions by a fluorescein-coumarin chemodosimeter. Bull. Korean Chem. Soc., vol.31, No.1, (January 2010), pp. 246-249, ISSN 0253-2964

Sakamoto, H.; Ishikawa, J.; Osuga, H.; Doi, K. \& Wada, H. (2010). Highly silver ion selective fluorescent ionophore: fluorescent properties of polythiazaalkane derivatives bearing 8-(7-hydroxy-4-methyl)coumarinyl moiety in aqueous solution and in liquid-liquid extraction systems. Analyst, vol.135, No.3, (February 2010), pp. 550558, ISSN 0003-2654 
Saleh, N.; Al-Soud, Y. A. \& Nau, W. M. (2008). Novel fluorescent pH sensor based on coumarin with piperazine and imidazole substituents. Spectrochim. Acta A, vol.71, No.3, (December 2008), pp. 818-822, ISSN 1386-1425

Santos, H. M.; Pedras, B.; Tamayo, A.; Casabó, J.; Escriche, L.; Covelo, B.; Capelo, J. L. \& Lodeiro, C. (2009). New chemosensors based on thiomacrocycle-containing coumarin-343 fluoroionophor: X-ray structures and previous results on the effect of cation binding on the photophysical properties. Inorg. Chem. Commun., vol.12, No.11, (November 2009), pp. 1128-1134, ISSN 1387-7003

Sato, S.; Suzuki, M.; Soma, T. \& Tsunoda, M. (2008). Synthesis and properties of umbelliferone-nitroxide radical hybrid compounds as fluorescence and spin-label probes. Spectrochim. Acta A, vol.70, No.4, (September 2008), pp. 799-804, ISSN 13861425

Secor, K. E. \& Glass, T. E. (2004). Selective amine recognition: development of a chemosensor for dopamine and norepinephrine. Org. Lett., vol.6, No.21, (October 2004), pp. 3727-3730, ISSN 1523-7060

Sethna, S. M. \& Shah, N. M. (1945). The chemistry of coumarins. Chem. Rev., vol.36, No.1, (February 1945), pp. 1-62, ISSN 0009-2665

Shao, J. (2010). A novel colorimetric and fluorescence anion sensor with a urea group as binding site and a coumarin group as signal unit. Dyes Pigments, vol.87, No.3, (November 2010), pp. 272-276, ISSN 0143-7208

Sheng, J. R.; Feng, F.; Qiang, Y.; Liang, F. G.; Sen, L. \& Wei, F.-H. (2008). A coumarin-derived fluorescence chemosensors selective for copper(II). Anal. Lett., vol.41, No.12, (August 2008), pp. 2203-2213, ISSN 0003-2719

Sheng, R.; Wang, P.; Liu, W.; Wu, X. \& Wu, S. (2008). A new colorimetric chemosensor for $\mathrm{Hg}^{2+}$ based on coumarin azine derivatives. Sensors Actuators B, vol.128, No.2, (January 2008), pp. 507-511, ISSN 0925-4005

Shibata, A.; Abe, H.; Ito, M.; Kondo, Y.; Shimizu, S.; Aikawa, K. \& Ito, Y. (2009). DNA templated nucleophilic aromatic substitution reactions for fluorogenic sensing of oligonucleotides. Chem. Commun., No.43, (November 2009), pp. 6586-6588, ISSN 1359-7345

Shiraishi, Y.; Sumiya, S. \& Hirai, T. (2010). A coumarin-thiourea conjugate as a fluorescent probe for $\mathrm{Hg}(\mathrm{II})$ in aqueous media with a broad $\mathrm{pH}$ range 2-12. Org. Biomol. Chem., vol.8, No.6, (March 2010), pp. 1310-1314, ISSN 1477-0520

Shiraishi, Y.; Sumiya, S. \& Hirai, T. (2011). Highly sensitive cyanide anion detection with a coumarin-spiropyran conjugate as a fluorescent receptor. Chem. Commun., vol.47, No.17, (May 2011), pp. 4953-4955, ISSN 1359-7345

Singh, R. K.; Mandal, T.; Balasubramanian, N.; Cook, G. \& Srivastava, D. K. (2011). Coumarin-suberoylanilide hydroxamic acid as a fluorescent probe for determining binding affinities and off-rates of histone deacetylase inhibitors. Anal. Biochem., vol.408, No.2, (January 2011), pp. 309-315, ISSN 0003-2697

Sokkalingam, P. \& Lee, C.-H. (2011). Highly sensitive fluorescence "turn-on" indicator for fluoride anion with remarkable selectivity in organic and aqueous media. J. Org. Chem., vol.76, No.10, (May 2011), pp. 3820-3828, ISSN 0022-3263

Su, Z.; Chen, K.; Guo, Y.; Qi, H.; Yang, X.-F. \& Zhao, M.. (2010). A coumarin-based fluorescent chemosensor for $\mathrm{Zn}^{2+}$ in aqueous ethanol media. J. Fluoresc., vol.20, No.4, (July 2010), pp. 851-856, ISSN 1053-0509

Suresh, M. \& Das, A. (2009). New coumarin-based sensor molecule for magnesium and calcium ions. Tetrahedron Lett., vol.50, No.42, (October 2009), pp. 5808-5812, ISSN 0040-4039 
Suzuki, Y.; Komatsu, H.; Ikeda, T.; Saito, N.; Araki, S.; Citterio, D.; Hisamoto, H.; Kitamura, Y.; Kubota, T.; Nakagawa, J.; Oka, K. \& Suzuki, K. (2002). Design and synthesis of $\mathrm{Mg}^{2+}$-selective fluoroionophores based on a coumarin derivative and application for $\mathrm{Mg}^{2+}$ measurement in a living cell. Anal. Chem., vol.74, No.6, (March 2002), pp. 1423-1428, ISSN 0003-2700

Taki, M.; Desaki, M.; Ojida, A.; Iyoshi, S.; Hirayama, T.; Hamachi, I. \& Yamamoto, Y. (2008). Fluorescence imaging of intracellular cadmium using a dual-excitation ratiometric chemosensor. J. Am. Chem. Soc., vol.130, No.38, (September 2008), pp. 12564-12565, ISSN 0002-7863

Trenor, S. R.; Shultz, A. R.; Love, B. J. \& Long, T. E. (2004). Coumarins in polymers: from light harvesting to photo-cross-linkable tissue scaffolds. Chem. Rev., vol.104, No.6, (June 2004), pp. 3059-3077, ISSN 0009-2665

Tsai, C.-S.; Liu, P.-Y.; Yen, H.-Y.; Hsu, T.-L. \& Wong, C.-H. (2010). Development of trifunctional probes for glycoproteomic analysis. Chem. Commun., vol.46, No.30, (August 2010), pp. 5575-5577, ISSN 1359-7345

Tsukamoto, K.; Shinohara, Y.; Iwasaki, S. \& Maeda, H. (2011). A coumarin-based fluorescent probe for $\mathrm{Hg}^{2+}$ and $\mathrm{Ag}^{+}$with an $\mathrm{N}^{\prime}$-acetylthioureido group as a fluorescence switch. Chem. Commun., vol.47, No.17, (May 2011), pp. 5073-5075, ISSN 1359-7345

Upadhyay, K. K. \& Mishra, R. K. (2010). $\mathrm{Zn}^{2+}$ specific colorimetric receptor based on coumarin. Bull. Chem. Soc. Jpn., vol.83, No.10, (October 2010), pp. 1211-1215, ISSN 0009-2673

Upadhyay, K. K.; Mishra, R. K.; Kumar, V. \& Chowdhury, P. K. R. (2010a). A coumarin based ICT probe for fluoride in aqueous medium with its real application. Talanta, vol.82, No.1, (June 2010), pp. 312-318, ISSN 0039-9140

Upadhyay, K. K.; Mishra, R. K.; Kumar, A.; Zhao, J. \& Prasad, R. (2010b). Self assembled pseudo double helix architecture and anion sensing behavior of a coumarin based ICT probe. J. Mol. Struct., vol.963, No.2-3, (January 2010), pp. 228-233, ISSN 00222860

Vasylevska, A. S.; Karasyov, A. A.; Borisov, S. M. \& Krause, C. (2007). Novel coumarinbased fluorescent $\mathrm{pH}$ indicators, probes and membranes covering a broad $\mathrm{pH}$ range. Anal. Bioanal. Chem., vol.387, No.6, (March 2007), pp. 2131-2141, ISSN 16182642

Voutsadaki, S.; Tsikalas, G. K.; Klontzas, E.; Froudakis, G. E. \& Katerinopoulos, H. E. (2010). A "turn-on" coumarin-based fluorescent sensor with high selectivity for mercury ions in aqueous media. Chem. Commun., vol.46, No.19, (May 2010), pp. 3292-3294, ISSN 1359-7345

Wallace, K. J.; Fagbemi, R. I.; Folmer-Andersen, F. J.; Morey, J.; Lynth, V. M. \& Anslyn, E. V. (2006). Detection of chemical warfare simulants by phosphorylation of a coumarin oximate. Chem. Commun., No.37, (October 2006), pp. 3886-3888, ISSN 1359-7345

Wang, J.; Qian, X. \& Cui, J. (2006). Detecting $\mathrm{Hg}^{2+}$ ions with an ICT fluorescent sensor molecule: remarkable emission spectra shift and unique selectivity. J. Org. Chem., vol.71, No.11, (May 2006), pp. 4308-4311, ISSN 0022-3263

Welser, K.; Perera, M. D. A.; Aylott, J. W. \& Chan, W. C. (2009). A facile method to clickable sensing polymeric nanoparticles. Chem. Commun., No.43, (November 2009), pp. 6601-6603, ISSN 1359-7345

Wu, J.; Sheng, R.; Liu, W.; Wang, P.; Ma, J.; Zhang, H. \& Zhuang, X. (2011). Reversible fluorescent probe for highly selective detection of mercapto biomolecules. Inorg. Chem., vol.50, No.14, (July 2011), pp. 6543-6551, ISSN 0020-1669 
Wu, W.; Wu, W.; Ji, S.; Guo, H. \& Zhao, J. (2011). Accessing the long-lived emissive 3IL triplet excited states of coumarin fluorophores by direct cyclometallation and its application for oxygen sensing and upconversion. Dalton Trans., vol.40, No.22, (June 2011), pp. 5953-5963, ISSN 1477-9226

Xiao, D.; Martini, L. A.; Snoeberger III, R. C.; Crabtree, R. H. \& Batista, V. S. (2011). Inverse design and synthesis of acac-coumarin anchors for robust $\mathrm{TiO}_{2}$ sensitization. J. Am. Chem. Soc., vol.133, No.23, (June 2011), pp. 9014-9022, ISSN 0002-7863

Xie, Y.; Dix, A. V. \& Tor, Y. (2009). FRET enabled real time detection of RNA-small molecule binding. J. Am. Chem. Soc., vol.131, No.48, (December 2009), pp. 17605-17614, ISSN $0002-7863$

Xiong, M.; Xi, H.; Fu, Y. \& Sun, X. (2010). Synthesis and properties of novel coumarin-based fluorescent probes for identifying melamine. Chin. J. Org. Chem., vol.30, No.6, (June 2010), pp. 908-911, ISSN 0253-2786

Yan, M.; Li, T. \& Yang, Z. (2011). A novel coumarin Schiff-base as a Zn(II) ion fluorescent sensor. Inorg. Chem. Commun., vol.14, No.3, (March 2011), pp. 463-465, ISSN 13877003

Yao, J.; Dou, W.; Qin, W. \& Liu, W. (2009). A new coumarin-based chemosensor for $\mathrm{Fe}^{3+}$ in water. Inorg. Chem. Commun., vol.12, No.2, (February 2009), pp. 116-118, ISSN 13877003

Yi, L.; Li, H.; Sun, L.; Liu, L.; Zhang, C. \& Xi, Z. (2009). A highly sensitive fluorescence probe for fast thiol-quantification assay of glutathione reductase. Angew. Chem. Int. Ed., vol.48, No.22, (May 2009), pp. 4034-4037, ISSN 1433-7851

Yuan, L.; Lin, W. \& Song, J. (2010). Ratiometric fluorescent detection of intracellular hydroxyl radicals based on a hybrid coumarin-cyanine platform. Chem. Commun., vol.46, No.42, (November 2010), pp. 7930-7932, ISSN 1359-7345

Yuan, L.; Lin, W. \& Yang, Y. (2011). A ratiometric fluorescent probe for specific detection of cysteine over homocysteine and glutathione based on the drastic distinction in the kinetic profiles. Chem. Commun., vol.47, No.22, (June 2011), pp. 6275-6277, ISSN 1359-7345

Zhang, H. \& Rudkevich, D. M. (2007). A FRET approach to phosgene detection. Chem. Commun., No.12, (March 2007), pp. 1238-1239, ISSN 1359-7345

Zhao, X.; Zhang, Y.; He, G. \& Zhou, P. (2010). Highly sensitive fluorescent coumarin-based probes for selective detection of copper ion. Chin. J. Lumin., vol.31, No.3, (June 2010), pp. 433-438, ISSN 1000-7032

Zhou, Y.; Liu, K.; Li, J.-Y.; Fang, Y.; Zhao, T.-C. \& Yao, C. (2011). Visualization of nitroxyl in living cells by a chelated copper(II) coumarin complex. Org. Lett., vol.13, No.6, (March 2011), pp. 1290-1293, ISSN 1523-7060

Zhuang, X.; Liu, W.; Wu, J.; Zhang, H. \& Wang, P. (2011). A novel fluoride ion colorimetric chemosensor based on coumarin. Spectrochim. Acta A, vol.79, No.5, (September 2011), pp. 1352-1355, ISSN 1386-1425

Zuo, Q.-P.; Li, B.; Pei, Q.; Li, Z. \& Liu, S.-K. (2010). A highly selective fluorescent probe for detection of biological samples thiol and its application in living cells. J. Fluoresc., vol.20, No.6, (November 2010), pp. 1307-1313, ISSN 1053-0509 


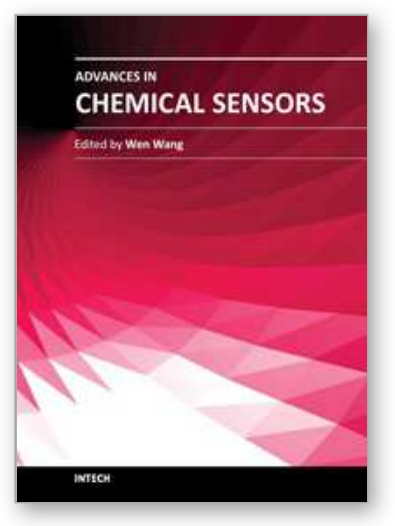

\author{
Advances in Chemical Sensors \\ Edited by Prof. Wen Wang
}

ISBN 978-953-307-792-5

Hard cover, 358 pages

Publisher InTech

Published online 20, January, 2012

Published in print edition January, 2012

The chemical sensor plays an essential role in the fields of environmental conservation and monitoring, disaster and disease prevention, and industrial analysis. A typical chemical sensor is a device that transforms chemical information in a selective and reversible way, ranging from the concentration of a specific sample component to total composition analysis, into an analytically useful signal. Much research work has been performed to achieve a chemical sensor with such excellent qualities as quick response, low cost, small size, superior sensitivity, good reversibility and selectivity, and excellent detection limit. This book introduces the latest advances on chemical sensors. It consists of 15 chapters composed by the researchers active in the field of chemical sensors, and is divided into 5 sections according to the classification following the principles of signal transducer. This collection of up-to-date information and the latest research progress on chemical sensor will provide valuable references and learning materials for all those working in the field of chemical sensors.

\title{
How to reference
}

In order to correctly reference this scholarly work, feel free to copy and paste the following:

Hongqi Li, Li Cai and Zhen Chen (2012). Coumarin-Derived Fluorescent Chemosensors, Advances in Chemical Sensors, Prof. Wen Wang (Ed.), ISBN: 978-953-307-792-5, InTech, Available from: http://www.intechopen.com/books/advances-in-chemical-sensors/coumarin-derived-fluorescent-chemosensors

\section{INTECH}

open science | open minds

\section{InTech Europe}

University Campus STeP Ri

Slavka Krautzeka 83/A

51000 Rijeka, Croatia

Phone: +385 (51) 770447

Fax: +385 (51) 686166

www.intechopen.com

\section{InTech China}

Unit 405, Office Block, Hotel Equatorial Shanghai

No.65, Yan An Road (West), Shanghai, 200040, China

中国上海市延安西路65号上海国际贵都大饭店办公楼 405 单元

Phone: +86-21-62489820

Fax: $+86-21-62489821$ 
(C) 2012 The Author(s). Licensee IntechOpen. This is an open access article distributed under the terms of the Creative Commons Attribution 3.0 License, which permits unrestricted use, distribution, and reproduction in any medium, provided the original work is properly cited. 